\title{
ESSAY \\ VOTE FRAUD IN THE EYE OF THE BEHOLDER: THE ROLE OF PUBLIC OPINION IN THE CHALLENGE TO VOTER IDENTIFICATION REQUIREMENTS
}

\author{
Stephen Ansolabehere E Nathaniel Persily
}

TABLE OF CONTENTS

\begin{tabular}{|c|c|}
\hline & $\begin{array}{l}\text { THE FAMILIAR PLACE OF PERCEPTIONS IN THE DEBATE } \\
\text { OVER ELECTION FRAUD }\end{array}$ \\
\hline II. & 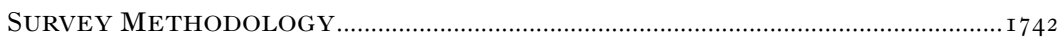 \\
\hline III. & BELIEFS in THE FREQUENCY OF VOTER Fraud, VOTER \\
\hline & IMPERSONATION, AND VOTE THEFT \\
\hline IV. & PERCEPTIONS OF FRAUD AND THE LIKELIHOOD OF VOTING ……..................I750 \\
\hline $\mathrm{V}$. & VOTER IDENTIFICATION AND FEARS OF FRAUD \\
\hline & CONCLUSIONS............ \\
\hline & ENDICES.... \\
\hline & APPENDIX A.. \\
\hline & APPENDIX B ..... \\
\hline & 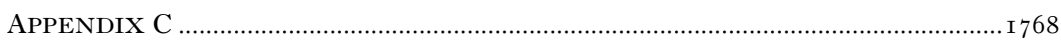 \\
\hline & APPENDIX D \\
\hline & APPENDIX E . \\
\hline & APPENDIX F A \\
\hline
\end{tabular}




\title{
VOTE FRAUD IN THE EYE OF THE BEHOLDER: THE ROLE OF PUBLIC OPINION IN THE CHALLENGE TO VOTER IDENTIFICATION REQUIREMENTS
}

\author{
Stephen Ansolabehere* \& Nathaniel Persily**
}

\begin{abstract}
In the current debate over the constitutionality of voter identification laws, both the Supreme Court and defenders of such laws have justified them, in part, as counteracting a widespread fear of vote fraud that leads citizens to disengage from the democracy. Because actual evidence of voter impersonation fraud is rare and difficult to come by if fraud is successful, reliance on public opinion as to the prevalence of fraud threatens to allow courts to evade the difficult task of balancing the actual constitutional risks involved. In this Essay we employ a unique survey to evaluate the causes and effects of public opinion regarding vote fraud. We find that perceptions of fraud have no relationship to an individual's likelihood of turning out to vote. We also find that voters who were subject to stricter identification requirements believe fraud is just as widespread as do voters subject to less restrictive identification requirements.
\end{abstract}

"Voter fraud drives honest citizens out of the democratic process and breeds distrust of our government. Voters who fear their legitimate votes will be outweighed by fraudulent ones will feel disenfranchised."1

The current debate over the constitutionality of laws mandating photo identification for voters presents a series of largely unanswered, and in some respects, unanswerable, empirical questions. For the most part, the parties to the litigation culminating in the case currently before the Supreme Court, Crawford v. Marion County Elections Board, ${ }^{2}$ have speculated about the number of illegal votes cast and the number of legal voters who would be prevented from voting were voting conditioned on the production of a driver's license or some other form of state-issued voter identification. When critics of voter ID requirements point to the lack of prosecutions or reported incidences of voter impersonation fraud, defenders of such laws reply, in part, that successful fraud goes undetected. When defenders of voter ID argue that

\footnotetext{
* Elting R. Morison Professor of Political Science, Massachusetts Institute of Technology.

** Professor of Law and Political Science, Columbia Law School. We are grateful for comments received from Elizabeth Emens, Heather Gerken, Richard Hasen, Richard Primus, Sam Hirsch, and participants in workshops at Stanford, Columbia, and University of Chicago law schools. We also thank the good folks at YouGovPolimetrix for their assistance with the public opinion polls discussed herein, and Laura Gleen for helpful research assistance.

1 Purcell v. Gonzalez, I 7 S. Ct. 5, 7 (2006) (per curiam) (emphasis added).

2472 F.3d 949 (7th Cir. 2007) (upholding Indiana photo identification law), cert. granted, I 28 S. Ct. 33 (2007).
} 
such laws lead to very few people being turned away from the polls or having their votes go uncounted, critics respond that even a violation of the voting rights of a few is constitutionally impermissible, and that precious little data exist to assess the impact of such laws on the currently voting population or the deterrent effect it might have on future voters. With the scarcity of empirical findings to settle some of the factual issues central to this debate, ${ }^{3}$ there is great risk that the Court will resign itself - as it hinted it might in Purcell $v$. Gonzalez, ${ }^{4}$ quoted above - to its intuition that "fear" of election fraud "drives honest citizens out of the democratic process." This intuition, however, presents a testable empirical proposition, which this Essay attempts to evaluate based on new survey data that assess the popular perception of election fraud and the likelihood that such beliefs lead to voter disengagement.

We begin this Essay in Part I by situating the argument about fears of fraud within the debate over voter identification requirements and election law more generally. The argument follows a path familiar to campaign finance law, in which the Court elided difficult questions about the empirics of campaign contributions and corruption by relying on the prevention of the appearance of corruption as a state interest sufficient to justify restrictions on campaign contributions and expenditures. $^{5}$ Part II describes the unique national survey we conducted to assess how widespread popular fear of two different types of election fraud is, and the relationship between such fear and the likelihood of people turning out to vote. Part III discusses our findings about the prevalence of perceptions of vote fraud and how those perceptions vary among political, racial, and other demographic subgroups. In Part IV, we present findings suggesting that such fears of fraud, while held by a sizable share of the population, do not have any relationship to a respondent's likelihood of intending to vote or turning out to vote. Part V then assesses whether voter identification

\footnotetext{
3 The studies submitted as part of the litigation are all unpublished. See Jeffrey MiLyo, The EFFects of Photographic Identification on Voter Turnout in Indiana: A COUNTY-LEVEL ANALYsis (2007), available at http://truman.missouri.edu/uploads/Publications/ Report\%2010-2007.pdf (demonstrating that voter turnout increased in Indiana after the implementation of photo ID requirements); R. Michael Alvarez et al., The Effect of Voter Identification Laws on Turnout (Cal. Inst. of Tech., Social Science Working Paper No. I267R, 2008) (demonstrating that certain types of ID requirement depress turnout for certain classes of citizens); Matt A. Barreto et al., The Disproportionate Impact of Indiana Voter ID Requirements on the Electorate (Nov. 8, 2007) (unpublished manuscript, on file with the Harvard Law School Library), available at http://depts.washington.edu/uwiser/documents/Indiana_voter.pdf (demonstrating that certain classes of citizens are less likely to have valid ID and suggesting that Indiana's voter ID law will have a disparate impact on such groups).

4 I27 S. Ct. 5.

5 See Nathaniel Persily \& Kelli Lammie, Perceptions of Corruption and Campaign Finance: When Public Opinion Determines Constitutional Law, I53 U. PA. L. REV. I 19 (2004).
} 
laws might make a difference in quelling such fears of fraud. We find that voters who have been forced to show identification are no less likely to perceive fraud than those not similarly subject to an ID requirement. Part VI presents our conclusions.

In this Essay, we do not endeavor to assess the extent of actual fraud or the likelihood of vote denial under a photo identification regime ${ }^{6}$ but we consider those to be the central empirical questions that should guide the decision over the constitutionality of voter ID laws. The Court should not seek refuge in this field, as it has in others, in putative conventional wisdom as to the alleged harms caused by widespread perceptions of a defect in American democracy or the ability of voter ID laws to address them. That conventional wisdom is wrong, we argue, and should not substitute for the admittedly challenging predictive judgments as to the greater constitutional threat posed by actual fraud or by attempts to prevent it. ${ }^{7}$

\section{The FAMiliar Place of PERCEPTIONS IN THE DEBATE OVER ELECTION FRAUD}

The dictum in Purcell concerning fears of election fraud may simply be an innocent attempt at armchair social science, but the parties to the Crawford litigation have not treated it as such. A dozen briefs filed in the case have taken the Court at its word that combating perceptions of fraud and concomitant declines in citizen engagement can justify voter identification laws. ${ }^{8}$

\footnotetext{
6 For such an assessment, see Stephen Ansolabehere, Access Versus Integrity in Voter Identification Requirements, ${ }_{3}$ N.Y.U. ANN. SURV. AM. L. (forthcoming May 2008).

7 See Spencer Overton, Voter Identification, I05 MICH. L. REV. 63I (2007) (arguing that some disenfranchisement due to voter ID requirements is certain whereas voter impersonation fraud is a hypothetical problem).

8 Briefs supporting the photo ID law and restating the Purcell argument include: Brief of the Am. Unity Legal Def. Fund as Amicus Curiae Supporting Affirmance at 23, Crawford v. Marion County Election Bd., Nos. 07-2 I \& 07-25 (U.S. Dec. I0, 2007); Brief for Lawyers Democracy Fund as Amicus Curiae in Support of the Respondents at 27 , Crawerord, Nos. 07-2 I \& 07-25 (U.S. Dec. IO, 2007); Brief of the Republican Nat'l Comm. as Amicus Curiae Supporting Respondents at 20, Craweford, Nos. 07-2 I \& 07-25 (U.S. Dec. 10, 2007); Brief of Texas et al. as Amici Curiae Supporting Respondents at 27 , Crawford, Nos. 07-2 I \& 07-25 (U.S. Dec. I0, 2007); Brief for the United States as Amicus Curiae Supporting Respondents at I8, 28, Crawford, Nos. 07-2 I \& 07-25 (U.S. Dec. I0, 2007); Brief of United States Senators Mitch McConnell et al. as Amici Curiae in Support of Respondents at 9, Craweford, Nos. 07-2 I \& 07-25 (U.S. Dec. Iо, 2007); Brief of Democrat and Republican Election Prof'ls as Amici Curiae in Support of Affirmance at 5, Crawford, Nos. O7-2 I \& 07-25 (U.S. Dec. 7, 2007); Amicus Curiae Brief of Mountain States Legal Found. in Support of Respondents at 24, Crawford, Nos. 07-2 I \& 07-25 (U.S. Dec. 7, 2007); Brief of State Respondents at 2 I, 53, Crawford, Nos. 07-2 I \& 07-25 (U.S. Dec. 3, 2007).

Briefs opposing the photo ID law that address the argument in Purcell include: Brief of Amici Curiae the Brennan Ctr. for Justice et al. in Support of Petitioners at 30, Crawford, Nos. 072 I \& 07-25 (U.S. Nov. I3, 2007); Brief of Amicus Curiae Professor Richard L. Hasen in Support of
} 
The state respondents' brief was most emphatic in its advocacy of a state interest in restoring confidence in elections. Citing Gallup and Rasmussen polls attesting to the widespread lack of confidence Americans have in the integrity of elections, the state's brief contained an entire subsection titled "The need to preserve public confidence in elections justifies the Voter ID Law." 9 Because opportunities for abuse exist, the brief argued, this state interest in restoring confidence is compelling "[r]egardless whether particular instances of fraud are well documented." 10

The state's brief and several others viewed the governmental interest here as analogous to the state's interest in using campaign finance regulations to combat the perception of corruption. ${ }^{11}$ In a series of cases beginning with Buckley $v$. Valeo ${ }^{12}$ and extending through $M c$ Connell v. FEC, ${ }^{13}$ the Court has said that "[o]f almost equal concern as the danger of actual quid pro quo arrangements is the impact of the appearance of corruption stemming from public awareness of the opportunities for abuse inherent in a regime of large individual financial contributions." ${ }^{14}$ In cases challenging the constitutionality of such laws, the defenders of campaign finance reforms point to news reports, testimony, and even public opinion polls suggesting that people view campaign contributors as having undue influence over government policy. ${ }^{15}$

As is the risk with the voter ID inquiry, this backup state interest founded on appearances and perceptions allows defendants (and judges) to escape from the more difficult task of proving the existence of actual corruption. In other words, it is much easier to prove that people believe campaign contributions often buy political favors than it is to demonstrate that such a dynamic, in fact, exists. Because a politician can almost always say "I would have voted that way anyway" and contributors can almost always say "we direct money to candidates who already share our beliefs," it will be very difficult to prove that a given contribution's recipient would have behaved differently in its absence. Indeed, such perceptions and appearances do not

Petitioners at 36-37, Craweford, Nos. 07-2 I \& 07-25 (U.S. Nov. 9, 2007); Brief for Petitioners [William Crawford et al.] at 53, Crawford, No. 07-2 I (U.S. Nov. 5, 2007).

9 Brief of State Respondents, supra note 8, at 53.

10 Id. at 54 .

11 See id.; Brief for Lawyers Democracy Fund as Amicus Curiae in Support of the Respondents, supra note 8, at 27; Brief of the Republican Nat'l Comm. as Amicus Curiae Supporting Respondents, supra note 8, at I4; Brief of Democrat and Republican Election Prof'ls as Amici Curiae in Support of Affirmance, supra note 8, at 34.

12424 U.S. I ( 1976$)$ (per curiam).

13 540 U.S. 93 (2003).

14 Buckley, 424 U.S. at 27 (per curiam); see also Nixon v. Shrink Mo. Gov't PAC, 528 U.S. 377 , 389 (2000).

15 See Persily \& Lammie, supra note 5 , at $\mathrm{I} 28-34$. 
even really depend on the existence of actual corruption, because awareness of the "opportunities for abuse" is sufficient to establish the state's interest. Nor does an analysis based on such perceptions necessarily imply that a particular remedy will be successful in removing them.

The argument is similar when it comes to vote fraud. Rather than undertake the more difficult task of proving its existence, ${ }^{16}$ it is much easier to look at a system's potential for abuse and to point to public opinion that suggests such abuse occurs with great frequency. In both contexts, one cannot quibble with the democratic value of such feelings of legitimacy in the abstract. That is, few would prefer a state of affairs in which people see government as corrupt or elections as rigged. However, if such opinions are insensitive to regulatory regime changes - that is, campaign contribution restrictions or photo ID laws - then something else must be responsible for these general feelings of distrust. ${ }^{17}$ Finally, if the importance of these beliefs is their relationship to citizen engagement, then such a relationship could easily be established by showing a correlation between such opinions and the likelihood of voting.

\section{SURVEY MethodolOGY}

Our study examines survey data from 2006, 2007, and 2008 to calculate how pervasive Americans believe vote fraud to be and to understand whether such beliefs affect a person's likelihood of voting. YouGovPolimetrix, ${ }^{18}$ of Palo Alto, California, conducted national matched-random sample surveys of American adults as part of the 2006 and 2007 Cooperative Congressional Election Studies (CCES). ${ }^{19}$ The 2006 survey included questions about voter identification and voter turnout, and the 2007 survey included questions about respondents' perceptions of different types of vote fraud. For our study, YouGovPolimetrix conducted an additional survey in 2008 in order to probe respondents' beliefs about voter impersonation fraud in particu-

\footnotetext{
16 See Crawford v. Marion County Elections Bd., 472 F.3d 949, 953 (7th Cir. 2007), cert. granted, I28 S. Ct. 33 (2007) (discussing reasons why states would have difficulty enforcing bans on voter impersonation).

17 See generally Margaret Levi \& Laura Stoker, Political Trust and Trustworthiness, 3 ANN. REV. POL. SCI. 475, 476-85 (2000) (reviewing the political science literature on trust in government, and describing survey data from the United States and other countries).

18 See http://www.polimetrix.com.

19 These data are available at http://web.mit.edu/polisci/portl/index.html (last visited Apr. 5, 2008); http://web.mit.edu/polisci/portl/cces/commoncontent.html (last visited Apr. 5, 2008); http:// web.mit.edu/polisci/portl/detailpages/fraud.html (last visited Apr. 5, 2008); and http://web.mit. edu/polisci/portl/detailpages/portlcces2007.html (last visited Apr. 5, 2008).
} 
lar. ${ }^{20}$ Although respondents were selected through various internetbased methods, the resulting sample mirrored the main demographic characteristics - gender, age, education, race, region, and income and the political characteristics, especially party identification and ideological orientation, of other surveys. ${ }^{21}$ Comparison of the sample with the observed vote in 2006 provides a validity check on the sample methodology. The predicted division of the 2006 vote from the CCES sample forecast the election outcomes in the U.S. Senate and governor elections quite well. ${ }^{22}$

The CCES was designed primarily to study the 2006 election and public opinion of legislative politics, but it included some questions about voter identification. The overall study consisted of a $36,500-$ person survey conducted through the collaborative efforts of thirtyseven universities organized into thirty-five teams. Each of the teams designed their own survey content to be administered to a rooo-person sample. Questions common to all of the teams (such as voter turnout, vote choice, and various demographics) were pooled into a common survey conducted under the same sampling frame and resulting in the large 36,500-person sample. A further sample of Io,000 respondents from the original 36,500 was drawn for a follow-up survey conducted in November 2007 . The MIT team designed the content for one subset of this follow-up study, which included a question on noncitizen voting and double voting as well as a question regarding ballot tampering. The MIT CCES 2007 survey, then, consisted of Iooo interviews of respondents who had previously participated in the original 2006 CCES. In addition, Ioo0 new cases were drawn for the 2007 MIT survey. That design resulted in a 2000-person national sample survey, which we analyze in this Essay.

Because the questions regarding vote fraud in the 2007 survey did not attempt to measure perceptions of voter impersonation fraud specifically, we placed another survey in the field during the weekend prior to the Super Tuesday primary elections on February 5, 2008. This national internet-based survey of rooo people, also conducted by YouGovPolimetrix under a design similar to that described above, included questions about the type of fraud at issue in the Crawford litigation. It also included a variation of the vote fraud question in the

20 For a discussion of the methodology of surveys of this type, see generally DougLAS RIVERS, SAMPle MATChING: RePRESENTATIVE SAMPLING FROM INTERNET PANELS, http:// web.mit.edu/polisci/portl/cces/material/sample_matching.pdf.

21 Because very low-income minorities and nonvoters were underrepresented, we weight the sample to offer some correction for this. In regression analyses, we control for information and education to compensate for possible biases.

22 See Press Release, Polimetrix, Handicapping the 2006 Election (Nov. 6, 2006), available at http://www.pollster.com/Polimetrix\% 20CCES\% 20Press\%2oRelease\%20 I ro6o6.pdf. 
earlier survey in order to gauge similarity in responses to questions asking about different types of fraud. The survey asked about intentions to vote in the 2008 general election, whereas the previous surveys had asked whether the respondent had voted in 2006 or intended to vote in the 2008 primaries.

\section{BELIEFS IN THE FREQUENCY OF VOTER FRAUD, VOTER IMPERSONATION, AND VOTE THEFT}

The survey questions concerning the frequency of election fraud attempted to gauge respondents' opinions on three distinct phenomena. The first, which involves the type of fraud at issue in the Purcell litigation, ${ }^{23}$ concerns the illegal casting of votes by noncitizens or the casting of more than one ballot by a voter. We term this "Voter Fraud." The second, which is most relevant to the Crawford litigation, concerns the attempt of one voter to vote using the name of another. We term this "Voter Impersonation." The final phenomenon, which concerns stealing or tampering with votes once cast, is what we call "Vote Theft." We recognize that assessing these three phenomena does not exhaust all possible types of election fraud. We also acknowledge that simple survey questions cannot perfectly capture the intricacies of the illegality alleged to be prevented by voter identification requirements. Nevertheless, the data begin to give a sense of how widespread the public considers certain election irregularities to be. The distribution of responses is also consistent with that found in other surveys on election fraud. ${ }^{24}$ The precise wording of the survey items appears below:

Voter Fraud (2007). It is illegal to vote more than once in an election or to vote if not a U.S. citizen. How frequently do you think such vote fraud occurs?

It is very common

It occurs occasionally

It occurs infrequently

It almost never occurs

Not sure

\footnotetext{
23 The law at issue in Purcell required voters to present proof of citizenship when registering to vote and to present identification when voting on election day. Purcell v. Gonzalez, I 7 S. Ct. 5,6 (2006).

24 See, e.g., Rasmussen Reports, National Survey of 800 Likely Voters, January 2-3, 2008, http://www.rasmussenreports.com/public_content/politics/current_events/general_current_events/ general_current_events_toplines/toplines_voter_id_january_2_3_2008 [hereinafter Jan. Survey].
} 
Voter Fraud (2008). ${ }^{25}$ It is also illegal to vote more than once in an election or to vote if not a U.S. citizen. How frequently do you think this occurs?

Version A (asked of half the sample)

Very often

Somewhat often

Rarely

Very rarely

Don't know

Version B (asked of half the sample)

It is very common

It occurs occasionally

It occurs infrequently

It almost never occurs

Don't know

Vote Theft (2007). Another form of fraud occurs when votes are stolen or tampered with. How frequently do you think such vote fraud occurs?

It is very common

It occurs occasionally

It occurs infrequently

It almost never occurs

Not sure

Voter Impersonation (2008). It is illegal for a person to claim to be another person, who is registered, and to cast that person's vote. How often do you think this occurs?

25 By asking respondents how frequently they thought "such vote fraud" occurs, the 2007 phrasing of the question may have primed respondents to express their concerns about voter fraud more generally, rather than the type of fraud asked about in the question. The 2008 question replaces "such vote fraud" with "this" so respondents are not at risk of answering a question about voter fraud more generally. As discussed later, the share agreeing to the top category dropped and to the bottom category increased. We also split the sample to see whether the offered categories affected the distribution of responses. For example, under the 2007 version a respondent might not have seen a difference between the second category ("occasionally") and the third ("infrequently"). The difference in the categories did not lead to any substantial effect on responses to the first and last categories but might have led to some shuffling among the intermediate categories. 
Very often

Somewhat often

Rarely

Very rarely

Don't know

The results from the surveys appear in Table I. In the 2007 survey, the findings with respect to Voter Fraud and Vote Theft were quite similar. About a quarter of respondents believed Voter Fraud $(26 \%)$ and Vote Theft (23\%) are very common. Another $36 \%$ and $37 \%$, respectively, believed Fraud and Theft occur occasionally. About a fifth said Voter Fraud (20\%) and Vote Theft (2r\%) occur infrequently, and only $8 \%$ say Fraud and Theft almost never occur. These numbers are consistent with a recent Rasmussen poll which found that $23 \%$ of likely voters agreed that "[i]n most elections, . . . large numbers of people [are] allowed to vote who are not eligible to vote." 26

The 2008 survey question on Voter Fraud, probably because of the change in question wording, revealed a decline in the top category to I $2 \%$ and $14 \%$ and an increase in the bottom category to $14 \%$ and I6\%. Nevertheless, a substantial share of the population (either $45 \%$ or $5 \mathrm{I} \%$ ) chose one of the top two categories, suggesting a large number of people believe such Fraud occurs with some regularity. A smaller share of the population believes Voter Impersonation is common. Only $9 \%$ think Voter Impersonation occurs very often, whereas $32 \%$ think it happens somewhat often. Still, 4I\% chose one of the two top categories.

TABLE I. BELIEFS IN THE FREQUENCY OF VOTER FRAUD, VOTER IMPERSONATION, AND VOTE THEFT

\begin{tabular}{||lcc||}
\hline \multicolumn{4}{|c||}{} & 2007 SURVEY (CCES) \\
\hline It Is Very Common & Voter Fraud & Vote Theft \\
It Occurs Occasionally & $26 \%$ & $23 \%$ \\
It Occurs Infrequently & 36 & 37 \\
It Almost Never Occurs & 20 & 2 I \\
Not Sure & 8 & 8 \\
\hline Number & I I & I0 \\
\hline \hline
\end{tabular}

\footnotetext{
26 Jan. Survey, supra note 24 .
} 


\begin{tabular}{||lccc||}
\hline \multicolumn{4}{|c||}{ 2008 SURVEY } \\
& $\begin{array}{l}\text { Voter Fraud } \\
\text { Version A }\end{array}$ & $\begin{array}{l}\text { Voter Fraud } \\
\text { Version B }\end{array}$ & $\begin{array}{l}\text { Voter } \\
\text { Impersonation }\end{array}$ \\
\hline Very Often/Very Common & I2\% & I4\% & $9 \%$ \\
Somewhat Often/Occasionally & 33 & 37 & 32 \\
Rare/Infrequent & 27 & 2 I & 27 \\
Very Rare/Almost Never & I4 & I6 & I5 \\
Don't Know & I3 & I2 & I7 \\
\hline Number & 483 & 507 & I000 \\
\hline
\end{tabular}

One potentially important lesson from the comparison of the various question wordings concerns the use of the words "vote fraud" in describing the behavior. Activities explicitly labeled "vote fraud" evoked expressions of beliefs in higher frequencies of the activity. The activities themselves, including noncitizen voting or voting multiple times, were thought to occur somewhat less often when simply described. This suggests to us that descriptions employing the catchphrase "vote fraud" prompt some people to overstate their beliefs in certain sorts of behaviors.

Political debate over identification requirements and vote fraud has exposed a partisan difference. Democrats tend to express greater worries about Vote Theft and Republicans express greater concerns about Voter Fraud. The survey data bear out the partisan orientation of beliefs about vote fraud. As shown in Appendix A, Democrats are only slightly more likely than Republicans to state that Vote Theft is very common. However, the partisan gap with respect to Fraud is much more pronounced. More than twice as many Republicans as Democrats consider Voter Fraud to be very common. Looking at the 2008 survey, the partisan division on Voter Impersonation follows the same pattern as that on Voter Fraud. Three out of ten Democrats (3I\%) said that they thought Voter Impersonation occurs Somewhat Often or Very Often, whereas fully half of all Republicans (53\%) said so. One in five Democrats (2I\%) thought Impersonation occurs Very Rarely, but just one in twenty Republicans (5\%) said the same. In the 2008 sample, $58 \%$ of Republicans said Fraud occurs Somewhat Often or Very Often, compared with $39 \%$ of Democrats. Party remains a significant predictor of beliefs about both Fraud and Impersonation in a multivariate analysis that controls for ideology, education, age, race, income, and region. ${ }^{27}$

27 See infra tbl.4. 
Other demographic and political variables also help explain people's beliefs about the frequency of Fraud, Theft, and Impersonation. Ideology (an individual's self-placement on a liberal to conservative continuum) does an even better job than partisanship in explaining attitudes as to the prevalence of Fraud. Whereas $46 \%$ of those in the 2007 survey who describe themselves as very conservative believe Fraud is very common, only $16 \%$ of those who describe themselves as very liberal hold a similar view. The same pattern holds for Voter Impersonation in the 2008 survey $-30 \%$ of those who describe themselves as very liberal believe Impersonation occurs very often or somewhat often, whereas $53 \%$ of those who call themselves very conservative give the same response. Ideology cuts the opposite way on Vote Theft, with liberal respondents thinking it more likely to occur than conservative respondents.

The racial gap in opinion concerning Voter Fraud and Vote Theft is much smaller than the ideological divide. In the 2007 survey, I6\% of blacks, 21\% of Hispanics, and $27 \%$ of whites said Fraud is very common. ${ }^{28}$ The 2008 survey showed no racial differences concerning beliefs in Fraud. As for Vote Theft, $24 \%$ of whites and of blacks and I $7 \%$ of Hispanics in the 2007 survey said it was very common. These small racial differences become statistically insignificant upon controlling for other factors, especially party and ideology. ${ }^{29}$ However, race does play a statistically significant role concerning beliefs about Voter Impersonation. The 2008 survey showed that whites are significantly less likely than other racial groups to believe that Impersonation occurs somewhat often or very often, even after controlling for income, age, ideology, education, region, and political attitudes.

Education and age also proved important in explaining beliefs about different sorts of vote fraud. Both correlated negatively with beliefs in the frequency of Fraud and Impersonation. Better educated people think Fraud is much less common than do less well educated people. Of those with a post-graduate degree, $9 \%$ said that Voter Impersonation occurs very often and $20 \%$ said it is very rare. By comparison, $15 \%$ of those without a high school degree think Impersonation occurs very often and only $8 \%$ think it is very rare. Using the 2007 survey question wording, we see a similar pattern. Of those in the highest education level, I $7 \%$ said Voter Fraud is very common and I $7 \%$ said it almost never occurs. Of those without a high school degree, however, $29 \%$ said Fraud is very common and only 5\% said it almost never occurs. Education is the only demographic variable

\footnotetext{
28 Surprisingly, there is no difference between whites and blacks in their beliefs as to the frequency of Vote Theft.

29 See infra tbl.4.
} 
that is consistently significant throughout each regression presented in Table 4 .

Partisan and demographic differences, however, distract from a more important commonality running through the data. Those who believe that one form of vote fraud occurs frequently are very likely to believe that the other form occurs frequently. As Table 2 describes, belief in Fraud is strongly, positively correlated with belief in Theft $(\mathrm{r}=.5 \mathrm{I})$ and in Voter Impersonation $(\mathrm{r}=.75)$. Of those who think Voter Fraud is very common, for example, $59 \%$ think Vote Theft is very common and $47 \%$ think Voter Impersonation occurs very often. Partisan differences are of secondary importance. ${ }^{30}$ People who have low levels of confidence in the integrity of elections tend to be consistent in their beliefs across different metrics of election mischief.

\section{TABLE 2. BELIEF IN FREQUENCY OF VOTE THEFT OR VOTER IMPERSONATION GIVEN BELIEF IN FREQUENCY OF VOTER FRAUD}

\begin{tabular}{|c|c|c|c|c|c|}
\hline \multicolumn{6}{|c|}{2007 SURVEY } \\
\hline \multicolumn{6}{|c|}{ Frequency of Vote Theft } \\
\hline & $\begin{array}{l}\text { Very } \\
\text { Common }\end{array}$ & Occasionally & Infrequently & Never & Not Sure \\
\hline \multicolumn{6}{|l|}{ Voter Fraud } \\
\hline Very Common & $59 \%$ & 29 & 9 & 2 & 5 \\
\hline Occasionally & $13 \%$ & 60 & I8 & 5 & 5 \\
\hline Infrequently & $8 \%$ & 28 & $5 \mathrm{I}$ & IO & 4 \\
\hline Almost Never & $17 \%$ & I 8 & $2 \mathrm{I}$ & 44 & 0 \\
\hline Not Sure & $6 \%$ & $\mathrm{I} 4$ & 3 & $\mathrm{I}$ & 75 \\
\hline \multicolumn{6}{|c|}{2008 SURVEY } \\
\hline \multicolumn{6}{|c|}{ Frequency of Voter Impersonation } \\
\hline & $\begin{array}{l}\text { Very } \\
\text { Often }\end{array}$ & $\begin{array}{l}\text { Somewhat } \\
\text { Often }\end{array}$ & Rarely & $\begin{array}{l}\text { Very } \\
\text { Rarely }\end{array}$ & Not Sure \\
\hline \multicolumn{6}{|l|}{ Voter Fraud } \\
\hline Very Often & $47 \%$ & 42 & 8 & o & 3 \\
\hline Somewhat Often & $7 \%$ & 60 & $2 \mathrm{I}$ & 3 & 8 \\
\hline Rarely & I\% & I9 & 56 & I 8 & 7 \\
\hline Very Rarely & ०\% & 5 & 26 & $6 \mathrm{I}$ & 7 \\
\hline Not Sure & I $\%$ & 5 & 8 & I & 84 \\
\hline
\end{tabular}

30 The Rasmussen poll concerning vote fraud similarly found modest differences among partisans. Fourteen percent of Democrats and $36 \%$ of Republicans believe that "[i]n most elections, large numbers of people are allowed to vote who are not eligible to vote." See Jan. Survey, supra note 24. When we added Vote Theft into a regression (not presented here) with Voter Fraud as the dependent variable, only partisanship and perceptions of Vote Theft, but none of the demographic variables, remained statistically significant. 


\section{PERCEPTIONS OF FRAUd AND THE LIKELIHOOd OF VOTING}

The Purcell dictum and the Crawford briefs suggest that widespread perception of fraud weakens public confidence in the electoral process and thereby lowers participation. Requiring voters to show photo identification, it is asserted, will appear to stem illegal voting, thereby restoring the confidence of legal voters in the process.

These arguments point to a specific empirical prediction. Perceptions of higher rates of vote fraud ought to correlate negatively with participation in the electoral process. This is a novel conjecture within the academic research on voter turnout and has not been subject to empirical study. Past research has found correlations between an individual's sense of political efficacy and his or her reported vote and intentions to vote. ${ }^{31}$ Also, researchers have examined the connection between electoral laws, such as the Voting Rights Act or election day registration provisions, and turnout. ${ }^{32}$ But we know of no research that examines the connection between beliefs about fraud and the likelihood of voting.

We can test this conjecture directly using our survey data. The prediction holds that there should be a negative correlation between the perceived frequency of fraud and the propensity to vote. The 2007 survey contains three distinct measures of voting: Reported Vote (in the 2006 general election), Validated Vote (in the 2006 general election), and Intended Vote (in the 2008 presidential primary). The relationship between these different measures is presented in Appendix B. The 2008 survey asked respondents whether they were registered, whether they voted in the 2006 general election, and whether they intended to vote in the 2008 general election.

Reported Vote reflects the respondents' own reports as to whether they voted in the 2006 general election. Reported Vote is the most commonly studied indicator of political participation, even though it is well known that it exaggerates actual levels of participation because of measurement error and misreporting. In the 2004 American National Election Study, $79 \%$ reported voting in the general election. ${ }^{33}$ Actual turnout was approximately 20 percentage points lower. ${ }^{34}$ This incon-

\footnotetext{
31 See Steven J. Rosenstone \& John Mark Hansen, Mobilization, ParticipaTION, AND DEMOCRACY IN AMERICA I4I-45 (I993).

32 See id. at 196-209.

33 This percentage was calculated by the authors from the American National Election Survey. Ctr. For Political Studies, Univ. of Mich., The 2004 National Election Study, at variable V0450I8X, http://www.electionstudies.org/studypages/2004prepost/2004prepost.htm (last visited Apr. 5, 2008).

34 See U.S. Election Assistance Comm'N, A Summary of The 2004 Election Day SURVEY 5 (2005), available at http://www.eac.gov/clearinghouse/docs/eds2004/2004-election-daysurvey/.
} 
sistency arises from a mix of incorrect reporting and sample selection. ${ }^{35}$ Our sample was no exception: $70 \%$ in the 2007 survey and $67 \%$ in the 2008 survey reported voting in the 2006 midterm election; actual participation rates were approximately $40 \% .^{36}$

Because surveys of voter turnout tend to misrepresent the voting population, achieving a more accurate measure of turnout requires the more labor-intensive endeavor of independently verifying which survey respondents, in fact, turned out to vote. Validated Vote indicates survey respondents who actually voted according to the most accurate official election records, regardless of how they responded to the questions. We describe the process of constructing this measure in greater detail in Appendix B.

Intent To Vote in the 2008 presidential primary or general election provides a third indicator of participation. The survey asked voters in November of 2007 whether they intended to vote in the coming 2008 presidential primary elections and, if so, for which party and which candidate. Like Reported Vote, stated intentions to vote tend to exaggerate actual behavior. In the 2007 sample, $72 \%$ said they intended to vote in the primary. We view this not as a measure of behavior so much as a measure of psychological attachment to the process and interest in electoral politics. In the 2008 survey, an even greater percentage $(78 \%)$ expressed their intention to vote in the 2008 general election.

We examine how each of these measures of electoral participation (Reported, Validated, and Intended) varies with perceptions of the frequency of Voter Fraud, Voter Impersonation, and Vote Theft. Table 3 presents the percentage of survey respondents with Reported Vote, Validated Vote, or Intent To Vote within each level of the three measures of belief in vote fraud. The value of $77 \%$ in the first entry, for instance, means that $77 \%$ of those who think Voter Fraud is very common reported that they voted in the 2006 general election. If the Purcell theory of citizen engagement were true, voter participation should be lower among those who think Fraud or Impersonation occurs very often.

No such correlation emerges. Those who are not sure how much fraud occurs in the electoral process exhibit the lowest participation rates across all measures. Among those who had some belief about the extent of Fraud or Impersonation, the correlation between that belief and turnout proved extremely weak and almost always statistically insignificant. Inspection of each of the columns in Table 3 shows that

\footnotetext{
35 See Brian D. Silver, Barbara A. Anderson \& Paul R. Abramson, Who Overreports Voting?, 80 AM. POL. SCI. REV. 6I 3, 6I5 (I986) (concluding that educated people overreport turnout).

36 U.S. Election Assistance Comm'N, The 2006 Election Administration AND VOTING SURVEY i3 (2007), available at http://www.eac.gov/clearinghouse/docs/eds-2006/2006eds-votes-and-turnout.pdf/attachment_download/file.
} 
Reported Vote, Validated Vote, and Intent To Vote are nearly invariant to beliefs about Voter Fraud, Vote Theft, and Voter Impersonation. ${ }^{37}$

Even apart from this absence of empirical support, it is not obvious as a theoretical matter why a person who perceives a lot of fraud would not vote. If the advocates of this hypothesis adhere to some rational actor model, then the potential effect of a vote even under conditions of great fraud will still give the voter at least some chance to influence the outcome of an election. Staying home ensures that the voter has no effect. Of course, strictly speaking, rational actor models cannot explain why people vote at all, given the low likelihood that a voter will cast the tie-breaking vote in an election. ${ }^{38}$ However, assuming people vote because of some instrumental benefit, fraud will not reduce that benefit to zero (therefore equal to not voting) unless the voter knows that so much fraud will take place that his vote is certain not to make a difference. Indeed, it is also possible that fear of fraud will mobilize voters to turn out in order to counteract it. It seems more plausible that the rationale for refusing to vote under conditions of vote fraud reflects some kind of disgust for a corrupt system. In other words, voters will disengage not because there is no point in voting, but rather because the electoral system is perceived to be so corrupt that some voters simply do not want to be a part of it. Whatever the mechanics that underlie this hypothesis, the data reject it as an accurate description of present-day America.

\footnotetext{
37 See infra app. D.

38 See Anthony Downs, An Economic Theory of Democracy 274 (I957). Downs formalized an old puzzle. Learned Hand formulated the problem in his essay Democracy: Its Presumptions and Realities: "My vote is one of the most unimportant acts of my life; if I were to acquaint myself with the matters on which it ought really to depend, if I were to try to get a judgment on which I was willing to risk affairs of even the smallest moment, I should be doing nothing else, and that seems a fatuous conclusion to a fatuous undertaking." Learned Hand, $D e-$ mocracy: Its Presumptions and Realities (I932), reprinted in THE SPIRIT OF LIBERTY 90, 93 (Irving Dillard ed., 3d ed. I963). See also Donald P. Green \& IAN Shapiro, PATHOlogies of Rational Choice Theory: A Critique of Applications in Political Science 47-7I (1994) (reviewing the literature on the paradox of voter turnout).
} 
2008]

TABle 3. TURNOUT AND BELIEFS ABOUT THE FREQUENCY OF VOTER FRAUD, VOTE THEFT, AND VOTER IMPERSONATION

\begin{tabular}{|c|c|c|c|}
\hline \multicolumn{4}{|c|}{2007 SURVEY } \\
\hline & \multicolumn{3}{|c|}{ Turnout Indicator } \\
\hline & $\begin{array}{l}\text { Reported Vote in } \\
2006 \text { G.E. } \\
\% \text { Yes }\end{array}$ & $\begin{array}{l}\text { Validated Vote in } \\
2006 \text { G.E. } \\
\% \text { Yes }\end{array}$ & $\begin{array}{l}\text { Intent To Vote in } \\
2008 \text { P.E. } \\
\% \text { Definite }\end{array}$ \\
\hline \multicolumn{4}{|c|}{ Belief About Voter Fraud } \\
\hline Very Common & $77 \%$ & $45 \%$ & $80 \%$ \\
\hline Occasionally & 69 & 44 & 74 \\
\hline Infrequently & 70 & 43 & 66 \\
\hline Almost Never & 76 & $4^{2}$ & $8 \mathrm{I}$ \\
\hline Not Sure & 56 & 28 & 52 \\
\hline Overall & $70 \%$ & $42 \%$ & $72 \%$ \\
\hline Number of Cases & I976 & I 5 I I & I984 \\
\hline \multicolumn{4}{|l|}{ Correlations } \\
\hline Vote \& Belief & .04 & .02 & .06 \\
\hline Vote \& Not Sure & -.10 & -.10 &.- .16 \\
\hline \multicolumn{4}{|c|}{ Belief About Vote Theft } \\
\hline Very Common & $77 \%$ & $46 \%$ & $80 \%$ \\
\hline Occasionally & 70 & 43 & 72 \\
\hline Infrequently & 69 & 44 & 72 \\
\hline Almost Never & 67 & 38 & 72 \\
\hline Not Sure & 57 & 30 & 52 \\
\hline Overall & $70 \%$ & $42 \%$ & $72 \%$ \\
\hline Number of Cases & I927 & I 466 & I933 \\
\hline \multicolumn{4}{|l|}{ Correlations } \\
\hline Vote \& Belief & .06 & .04 & .06 \\
\hline Vote \& Not Sure & -.09 & -.08 &.- .15 \\
\hline
\end{tabular}




\begin{tabular}{|c|c|c|}
\hline \multicolumn{3}{|c|}{2008 SURVEY } \\
\hline & \multicolumn{2}{|c|}{ Turnout Indicator } \\
\hline & $\begin{array}{l}\text { Reported Vote in } 2006 \text { G.E. } \\
\% \text { Yes }\end{array}$ & $\begin{array}{l}\text { Intent To Vote in } 2008 \text { G.E. } \\
\% \text { Definite }\end{array}$ \\
\hline \multicolumn{3}{|l|}{$\begin{array}{l}\text { Belief About Voter } \\
\text { Impersonation }\end{array}$} \\
\hline Very Often & $74 \%$ & $80 \%$ \\
\hline Somewhat Often & 67 & 80 \\
\hline Rarely & 64 & 78 \\
\hline Very Rarely & 82 & 87 \\
\hline Not Sure & 57 & 67 \\
\hline Overall & $67 \%$ & $78 \%$ \\
\hline Number of Cases & 990 & 999 \\
\hline \multicolumn{3}{|l|}{ Correlations } \\
\hline Vote \& Belief & -.05 & -.05 \\
\hline Vote \& Not Sure &.$- \mathrm{II}$ & -.14 \\
\hline \multicolumn{3}{|l|}{$\begin{array}{l}\text { Belief About Voter } \\
\text { Fraud (Versions } \\
\text { A \& B Combined) }\end{array}$} \\
\hline Very Often & $81 \%$ & $83 \%$ \\
\hline Somewhat Often & 64 & 78 \\
\hline Rarely & 70 & 82 \\
\hline Very Rarely & $7 \mathrm{I}$ & 80 \\
\hline Not Sure & 54 & 63 \\
\hline Overall & $67 \%$ & $78 \%$ \\
\hline Number of Cases & 990 & 999 \\
\hline \multicolumn{3}{|l|}{ Correlations } \\
\hline Vote \& Belief & .02 & -.00 \\
\hline Vote \& Not Sure & -.10 & -.13 \\
\hline
\end{tabular}

\section{VOTER IDENTIFICATION AND FEARS OF FRAUD}

Not only did the dictum in Purcell posit that fears of vote fraud will lower citizen engagement, but the Court appeared to assume that voter identification laws, at least to some degree, will lessen those fears and bolster voter confidence in elections. ${ }^{39}$ Even if such fears do not reduce people's likelihood of voting, one might still say that voter ID laws are worth supporting if they bolster public confidence. However, the data that exist on the relationship between voter ID laws and fears of fraud do not support even this more modest argument.

We test this claim in three ways. First, we measure the effect of statewide frequency of the use of voter identification on individual participation rates. Second, we examine whether those who were

39 See Purcell v. Gonzalez, I27 S. Ct. 5, 7 (2006) (per curiam). 
asked to show photo identification in 2006 in fact had more confidence in the process in 2007 . Third, we examine whether residents in states with stricter identification requirements for voting, in fact, tend to think fraud happens less frequently.

The particular structure of the Cooperative Congressional Election Study allows us to measure the use of voter identification at the aggregate state level and the individual level. The 2006 CCES asked individuals whether they were asked to show picture identification when they voted. ${ }^{40}$ Approximately half of all voters said that they were asked to show photo identification, with the highest rates in the southern states and the lowest rates in the northeast. ${ }^{41}$ States served as the sampling frame for the $2006 \mathrm{CCES}$, and the very large 36,500-person sample creates sufficient density of cases in each state that we can aggregate the individual-level responses to the state level to estimate the frequency with which voter identification is required in the states. Of course, only a few states actually mandate photo identification as the only acceptable form of identification in order to vote. ${ }^{42}$ We suspect that most respondents who say they were asked for photo ID, in fact, were merely asked for some form of ID and they produced a photo ID - the most likely type of identification voters would have handy. Nevertheless, one might suspect that if more stringent identification requirements produce more confidence in elections, voters who say they needed to produce ID would have lower fears of fraud than those not similarly asked..$^{43}$ Moreover, although the aggregated responses differ from what the law on the books actually requires in many states, one still might expect that respondents from states where larger shares of people say they were required to produce a photo ID might have different views on the prevalence of fraud.

40 The 2006 CCES surveyed respondents before the general election and within a week after the election. The post-election battery asked:

Were you asked to show picture identification, such as a driver's license, at the polling place this November? Yes/No.

If Yes, were you then allowed to vote? Yes/No.

41 Ansolabehere, supra note 6 (manuscript at 7 , on file with the Harvard Law School Library).

42 See Electionline.org, Voter ID Laws, Jan. 23, 2008, http://www.pewcenteronthestates.org/ uploadedFiles/voter\%2oid\%2olaws.pdf. Only Florida, Georgia, and Indiana require all voters to show photo identification prior to casting a regular ballot. Id.

43 Of course, it is also possible that voter ID is most often required in areas where a greater fear of fraud precipitated the passage of a voter ID law. If so, then ID requirements might be a symptom of voters' fears of fraud, rather than a remedy. Another possibility is that voter ID laws lead people to worry that more fraud is present to be policed. Just as a large police presence in a neighborhood might heighten residents' fears of crime, so too might stringent voter ID laws cause voters to worry that fraud has made such requirements necessary. But, even if one of these theories were true, it would still contradict the notion that voter ID laws mitigate fears of election fraud. It may also be true that respondents answer the vote fraud question with respect to the nation as a whole, and not their state in particular. 
The data demonstrate no relationship between either individuallevel or aggregate rates of voter identification and perception of fraud. The correlations between beliefs about Voter Fraud and Vote Theft and the incidence of voter identification are very small and statistically indistinguishable from zero in both samples. In the 2007 survey, the correlations between an individual's showing identification in 2006 and belief in Voter Fraud and Vote Theft were -.or and .03, respectively. In the same survey, the correlation between the percentage of people in a state asked to show voter identification and belief in Voter Fraud and Vote Theft were .03 and .05, respectively. And in the 2008 survey, the correlations between the percentage of people in a state asked to show voter identification and beliefs in Voter Fraud and Voter Impersonation were -.02 and -.04, respectively. As the regressions presented in Table 4 and Appendix E explain, holding constant education, party identification, ideology, race, age, and other predictors did not improve matters. In none of the regressions do the measures of the incidence of the use of voter identification exhibit any significant relationship to any of the measures of beliefs about vote fraud. The strongest association arises with Impersonation, and the coefficient has the wrong sign (meaning that those subjected to photo ID requirements believe, if anything, that fraud is more prevalent). Whether the state or local election administration frequently asks for voter identification or not seems to have no relationship to individuals' beliefs about the frequency of Fraud or Impersonation. 
TABle 4. REgRESSION ANALYSIS OF THE EFFECTS OF VOTER IDENTIFICATION ON BELIEFS ABOUT VOTER FRAUD, VOTE THEFT, AND VOTER IMPERSONATION

\begin{tabular}{|c|c|c|c|c|}
\hline \multirow[b]{2}{*}{$\begin{array}{l}\text { Independent } \\
\text { Variables }\end{array}$} & \multicolumn{2}{|c|}{$\begin{array}{c}2007 \text { SURVEY } \\
\text { (Subsample interviewed } \\
\text { in } 2006 \text { and } 2007 \text { ) }\end{array}$} & \multicolumn{2}{|c|}{2008 SURVEY } \\
\hline & $\begin{array}{l}\text { Voter Fraud } \\
\text { Coeff. (S.E.) }\end{array}$ & \begin{tabular}{|l} 
Vote Theft \\
Coeff. (S.E.)
\end{tabular} & $\begin{array}{l}\text { Voter Fraud } \\
\text { Coeff. (S.E.) }\end{array}$ & $\begin{array}{l}\text { Impersonation } \\
\text { Coeff. (S.E.) }\end{array}$ \\
\hline$\%$ State ID & $.08(.13)$ & $-.06(.13)$ & $-.07(.12)$ & -.I6 (.II) \\
\hline Showed ID in 2006 & $-.06(.08)$ & $.06(.09)$ & N.A. & N.A. \\
\hline Democrat & $-.24(.08)^{*}$ &.$- .14(.09)$ & $-.28(.09)^{*}$ & $-.20(.08)^{*}$ \\
\hline Republican & $.22(.08)^{*}$ & $-.2 \mathrm{I}(. \mathrm{II})^{*}$ & $.18(.09)^{*}$ & $.12(.09)^{*}$ \\
\hline Ideology &.$- \operatorname{II}(.05)^{*}$ & $.01(.04)$ & $-.13(.04)^{*}$ & $-.16(.04)^{*}$ \\
\hline Income & $-.0 \mathrm{I}(. \mathrm{OI})$ & $-.0 \mathrm{I}(. \mathrm{OI})$ & $.00(.0 \mathrm{I})$ &. $\mathrm{OI}(. \mathrm{OI})$ \\
\hline Education & $-.08(.03)^{*}$ & $-.09(.03)^{*}$ & $-.08(.03)^{*}$ & $-.07(.02)^{*}$ \\
\hline Age & $-.02(.03)$ & $-.02(.03)$ & $.04(.02)$ & $.06(.02)^{*}$ \\
\hline White &. $\mathrm{I} 2(. \mathrm{II})$ &.$- \mathrm{I} 2(. \mathrm{II})$ & $-.06(.09)$ & -.I9 $(.09)^{*}$ \\
\hline Black & $-.05(.15)$ & $-.03(.15)$ &. $\mathrm{I} 6(. \mathrm{I} 3)$ & $.03(.12)$ \\
\hline South & $.03(.09)$ & $.03(.09)$ & $-.06(.08)$ & $.07(.08)$ \\
\hline Constant & $3.49(.24)$ & $3.56(.25)$ & $3.08(.22)$ & $3.06(.2 \mathrm{I})$ \\
\hline $\mathrm{N}$ & 703 & 687 & 726 & 709 \\
\hline R-Square & .09 & .03 &. $\mathrm{I} 2$ & .13 \\
\hline
\end{tabular}

N.A. $=$ Not Asked

* Statistically significant at .05 level.

The story is the same if we look at the correlation, or lack thereof, between the stringency of a state's voter identification requirements and its residents' perceptions of the frequency of fraud. First, we should note that there is (as we hoped and expected) a strong correlation $(+.78)$ between the stringency of a state's identification requirements and the share of the state's population in the CCES that reported being asked for photo identification. In order to characterize the stringency of a state's identification requirement, we adopt the categories supplied by Professors R. Michael Alvarez, Delia Bailey, and Jonathan Katz, who array states into categories depending on what kind of identification the state requires from voters at the polls. ${ }^{44}$

44 Alvarez et al., supra note 3, at 7-9, divide states according to the following categories: I. Voter must state his/her name.

2. Voter must sign his/her name in a poll-book.

3. Voter must sign his/her name in a poll-book and it must match a signature on file.

4. Voter is requested to present proof of identification or voter registration card.

5. Voter must present proof of identification or voter registration card.

6 . Voter must present proof of identification and his/her signature must match the signature on the identification provided.

7. Voter is requested to present photo identification.

8. Voter is required to present photo identification. 
The categorization of states, along with their associated rates of response to the CCES photo ID question, are presented in Appendix C.

We find no relationship between the stringency of a state's voter identification requirement in 2006 and the share of its population reporting that fraud occurs frequently. The sample sizes for our Fraud and Impersonation questions in the 2007 and 2008 surveys are too small to get accurate state-specific samples of perceptions of fraud. Nevertheless, what we do have shows that states that request or require photo identification do not have markedly different rates of perception of Fraud or Impersonation than those that merely require a signature from the voter, for example. Nationwide in 2008 , I3\% of the respondents believe Voter Fraud is very common, ${ }^{45}$ and $9 \%$ believe Impersonation occurs very often. In the four states with the strictest identification requirements, the beliefs in fraud are nearly identical to the national average: I4\% think Voter Fraud is very common and Io\% think Impersonation occurs very often. In the seven states with the least restrictive identification requirements, ${ }^{46}$ I I \% say Voter Fraud is very common and $8 \%$ say Impersonation occurs very often. In short, states differ in the share of the population that thinks fraud occurs frequently, but the stringency of their identification requirements is not responsible for those differences.

\section{CONCLUSIONS}

When judges base their decisions on untested empirical assumptions about political behavior, there is always a risk that a more serious inquiry into the data will prove them wrong. This risk is particularly great when judges attempt to assess American public opinion and its likely consequences. ${ }^{47}$ We think the Court made this mistake in Purcell and threatens to do so again in Crawford. We worry, in particular, that the issue of vote fraud and voter ID is ripe for such conjectures about perceptions because, as with campaign finance, the more relevant empirical claims about the existence of fraud and the potential

\footnotetext{
Id. (footnotes omitted).

45 This figure comes from the 2008 survey. In the 2007 survey, which identifies the activity as fraud, $26 \%$ thought that voting by those not eligible or voting multiple times occurs very often.

46 According to Professors Alvarez, Bailey, and Katz, the most stringent in 2006 were Florida, Louisiana, Hawaii, and Indiana. The least stringent were Maine, New Hampshire, North Carolina, Rhode Island, Utah, Vermont, and Wyoming. See Alvarez et al., supra note 3, at 8 \& n.8, 9 fig.I. The analysis presented here was also performed using the categorization of voter ID requirements by the National Conference of State Legislatures and the results were the same. See Nat'l Conference of State Legislatures, State Requirements for Voter ID, Jan. 9, 2008, http:// www.ncsl.org/programs/legismgt/elect/taskfc/voteridreq.htm.

47 See generally Nathaniel Persily, Introduction to PUBlic OPINION AND Constitutional Controversy 3, 4-7 (Nathaniel Persily et al. eds., 2008) (discussing the use of public opinion in constitutional cases).
} 
for disenfranchisement are so contested. Our exploration of the data presented here, however, suggests that casual assertions about popular beliefs should not substitute for the difficult balancing of the constitutional risks and probabilities of vote fraud and vote denial.

Although a sizable share of the population believes that vote fraud commonly or occasionally occurs, there is little or no relationship between beliefs about the frequency of fraud and electoral participation (reported, validated, or intended). Nor does it appear to be the case that universal voter identification requirements will raise levels of trust in the electoral process. Such fears appear unaffected by stricter voter ID laws, given that individuals asked to produce ID seem to have the same beliefs about the frequency of fraud as those not asked for ID.

We would not fault the Court for its very plausible, even if currently false, intuition. It makes sense to assume that as perceived fraud increases, the share of honest citizens willing to participate in the fraudulent system would decline. Election boycotts in the face of fears of election-rigging are commonplace in the developing world. ${ }^{48}$

We are also quite sympathetic to the broad principle that states should act to bolster confidence in elections. That confidence may be difficult to restore in the post-Bush v. Gore ${ }^{49}$ era, when any irregularity - real or hypothesized - is perceived as having the potential to decide even a national election. ${ }^{50}$ Nevertheless, states would do well to address real problems using real metrics for success, while weighing favorable effects on public opinion as a considerable side benefit. ${ }^{51}$

48 See, e.g., Clifford Krauss, Insurgent in Peru Calls for Election Boycott, N.Y. TIMEs, May 20, 2000, at A6; Marc Lacey, Congo, with Iraq in Mind, Faces Voting and Threats, N.Y. TIMES, Mar. 26, 2006, § I, at Io; Lydia Polgreen, Opposition in Senegal Boycotts Vote, N.Y. TIMES, June 4,2007 , at $\mathrm{A} 7$.

49 53 I U.S. 98 (2000).

50 The findings of this Essay are consistent with those of a separate analysis of the effect of perceived fairness of the resolution of the 2000 election controversy on subsequent voter turnout. In analysis of the relevant American National Election Studies (ANES) data (not presented here), we found no relationship between a respondent's perception of the fairness of the resolution of the 2000 election and the likelihood of that person turning out to vote in 2002 or in 2004 . The ANES conducted a panel study in which they interviewed the same respondents in 2000, 2002, and 2004 . In each year they asked respondents whether they thought the 2000 election had been decided fairly (questions Po23ri4x and Po45056) and whether they voted (Po25020 and Po45045x). The correlation between belief in the fairness of the 2000 election and voting was -.03 in 2002 and -.02 in 2004. See Ctr. for Political Studies, Univ. of Mich., National Election Study 2000-2002-2004 Full Panel File, http://www.electionstudies.org/studypages/2000to2004merged/2000to2004merged. htm (last visited Apr. 5, 2008) (presenting data from which the authors compiled the correlations presented here).

51 We should note that one state court has made this specific argument. The Supreme Court of Missouri, considering the Missouri photo ID law in Weinschenk v. State, 203 S.W.3d 201 (Mo. 2006), explained:

Appellants also urge that the State has a compelling interest in combating perceptions of voter fraud. While the State does have an interest in combating those perceptions, where the fundamental rights of Missouri citizens are at stake, more than mere percep- 
The use of photo identification requirements bears little correlation to the public's beliefs about the incidence of fraud. The possible relation of such beliefs to participation appears even more tenuous. This lack of empirical support leads us to conclude that, at least in the context of current American election practices and procedures, public perceptions do not provide a firm justification for voter identification laws.

tion is required for their abridgement. Perceptions are malleable. While it is agreed here that the State's concern about the perception of fraud is real, if this Court were to approve the placement of severe restrictions on Missourians' fundamental rights owing to the mere perception of a problem in this instance, then the tactic of shaping public misperception could be used in the future as a mechanism for further burdening the right to vote or other fundamental rights.... The protection of our most precious state constitutional rights must not founder in the tumultuous tides of public misperception. 


\section{APPENDICES}

\section{APPENDIX A}

TABle Ai. Distribution of Fraud Beliefs ACROSS POLITICAL AND DEMOGRAPHIC GROUPS, 2007 SURVEY

\begin{tabular}{|c|c|c|c|c|c|}
\hline & $\begin{array}{l}\text { Very } \\
\text { Common }\end{array}$ & $\begin{array}{l}\text { ter Fraud } \\
\text { Occasion- } \\
\text { ally }\end{array}$ & $\begin{array}{l}\text { Infre- } \\
\text { quently }\end{array}$ & $\begin{array}{l}\text { Never } \\
\text { Happens }\end{array}$ & Not Sure \\
\hline \multicolumn{6}{|l|}{ Party } \\
\hline Democrat $(33 \%)$ & I5\% & $36 \%$ & $23 \%$ & $13 \%$ & I3\% \\
\hline Republican (26\%) & 35 & 37 & I 7 & 5 & 7 \\
\hline Independent (27\%) & 29 & 36 & 22 & 7 & 7 \\
\hline \multicolumn{6}{|l|}{ Ideology } \\
\hline Very Liberal (5\%) & I6 & 32 & 27 & I6 & 9 \\
\hline Liberal (г 8\%) & I 2 & 34 & 32 & I4 & 9 \\
\hline Moderate $(35 \%)$ & 23 & 39 & 20 & 9 & IO \\
\hline Conservative $(22 \%)$ & 37 & 37 & I 5 & 5 & 5 \\
\hline Very Conservative (ıо\%) & 46 & $3 \mathrm{I}$ & $\mathrm{I} 2$ & 3 & 7 \\
\hline \multicolumn{6}{|l|}{ Race } \\
\hline White $(73 \%)$ & 27 & 37 & 20 & 6 & IO \\
\hline Black (I I \%) & I6 & 36 & 23 & I I & I4 \\
\hline Hispanic (I I \%) & $2 \mathrm{I}$ & 26 & 23 & I5 & I5 \\
\hline \multicolumn{6}{|l|}{ Education } \\
\hline No High School (4\%) & 29 & 28 & I6 & 5 & 23 \\
\hline High School (4I\%) & 28 & 37 & I6 & 5 & I 3 \\
\hline Some College (23\%) & 27 & 34 & $2 \mathrm{I}$ & 9 & 9 \\
\hline 2-year Degree (7\%) & $2 \mathrm{I}$ & 35 & $2 \mathrm{I}$ & I 2 & II \\
\hline 4-year Degree (I $7 \%)$ & 22 & 35 & 27 & 9 & 8 \\
\hline Post-graduate $(9 \%)$ & I 7 & 38 & 24 & $\mathrm{I} 7$ & 4 \\
\hline \multicolumn{6}{|l|}{ Generation } \\
\hline Born Before I928 (I\%) & 28 & 30 & 23 & 4 & I4 \\
\hline I928-I945 (I6\%) & 30 & 39 & I5 & IO & 6 \\
\hline I946-I960 (33\%) & 28 & 36 & $\mathrm{I} 7$ & 8 & I I \\
\hline I96I-I $973(24 \%)$ & 25 & 36 & 2 I & 9 & 9 \\
\hline I974-I $990(26 \%)$ & $2 \mathrm{I}$ & 33 & 24 & 7 & I5 \\
\hline \multicolumn{6}{|l|}{ Income } \\
\hline Ist Quintile & 30 & 32 & I 7 & 6 & I4 \\
\hline 2nd Quintile & 20 & 36 & 20 & 7 & I 8 \\
\hline 3rd Quintile & 23 & 40 & I9 & 7 & I I \\
\hline 4th Quintile & 29 & 35 & 22 & 7 & 7 \\
\hline 5th Quintile & 22 & 36 & 24 & $\mathrm{I} 2$ & 6 \\
\hline
\end{tabular}




\begin{tabular}{|c|c|c|c|c|c|}
\hline & $\begin{array}{l}\text { Very } \\
\text { Common }\end{array}$ & $\begin{array}{l}\text { Tote Theft } \\
\text { Occasion- } \\
\text { ally }\end{array}$ & $\begin{array}{l}\text { Infre- } \\
\text { quently }\end{array}$ & $\begin{array}{l}\text { Never } \\
\text { Happens }\end{array}$ & Not Sure \\
\hline \multicolumn{6}{|l|}{ Party } \\
\hline Democrat $(33 \%)$ & $23 \%$ & $38 \%$ & I9\% & $9 \%$ & II $\%$ \\
\hline Republican (26\%) & 20 & 36 & 25 & I I & 8 \\
\hline Independent $(27 \%)$ & 27 & 39 & $2 \mathrm{I}$ & 5 & 7 \\
\hline \multicolumn{6}{|l|}{ Ideology } \\
\hline Very Liberal (5\%) & 34 & 43 & I I & 3 & 9 \\
\hline Liberal (I8\%) & 23 & 38 & 22 & 7 & IO \\
\hline Moderate $(35 \%)$ & 24 & 39 & 2 I & 8 & 8 \\
\hline Conservative $(22 \%)$ & 22 & 35 & 23 & I 2 & 8 \\
\hline Very Conservative (Iо\%) & 28 & 39 & 20 & 6 & 6 \\
\hline \multicolumn{6}{|l|}{ Race } \\
\hline White $(73 \%)$ & 24 & 38 & 20 & 8 & IO \\
\hline Black ( I I \%) & 24 & 37 & 22 & 6 & I I \\
\hline Hispanic (I I \%) & I 7 & 39 & 22 & IO & $\mathrm{I} 2$ \\
\hline \multicolumn{6}{|l|}{ Education } \\
\hline No High School (4\%) & 25 & $3 \mathrm{I}$ & I9 & 4 & 20 \\
\hline High School (4I\%) & 25 & 37 & I 8 & 6 & I4 \\
\hline Some College (23\%) & 26 & 39 & 20 & 8 & 8 \\
\hline 2-year Degree (7\%) & 23 & 38 & 20 & IO & IO \\
\hline 4-year Degree (I $7 \%$ ) & I9 & 40 & 26 & 8 & 6 \\
\hline Post-graduate (9\%) & $\mathrm{I} 7$ & 34 & 26 & $\mathrm{I} 7$ & 5 \\
\hline \multicolumn{6}{|l|}{ Generation } \\
\hline Born Before I928 (г\%) & IO & 22 & 28 & 20 & 20 \\
\hline I928-I945 (I6\%) & 26 & 43 & I6 & IO & 5 \\
\hline I946-I960 (33\%) & 26 & 37 & I9 & 7 & I I \\
\hline I96I-I973 (24\%) & 2 I & 37 & 22 & IO & IO \\
\hline I974-I $990(26 \%)$ & $2 \mathrm{I}$ & 36 & 24 & 6 & I3 \\
\hline \multicolumn{6}{|l|}{ Income } \\
\hline Ist Quintile & 27 & 37 & I6 & 7 & I3 \\
\hline 2nd Quintile & 22 & 36 & I 8 & 7 & $\mathrm{I} 7$ \\
\hline 3rd Quintile & 23 & 40 & $2 \mathrm{I}$ & 6 & 9 \\
\hline 4th Quintile & 25 & 42 & I 8 & 7 & 8 \\
\hline 5th Quintile & 20 & 34 & 29 & $\mathrm{I} 2$ & 6 \\
\hline
\end{tabular}


TABle A2. Distribution OF FraUd Beliefs ACROSS POLITICAL AND DEMOGRAPHIC GROUPS, 2008 SURVEY

\begin{tabular}{|c|c|c|c|c|c|}
\hline & $\begin{array}{l}\text { Very } \\
\text { Often }\end{array}$ & $\begin{array}{l}\text { oter Fraud } \\
\text { Somewhat } \\
\text { Often }\end{array}$ & Rarely & $\begin{array}{l}\text { Very } \\
\text { Rarely }\end{array}$ & Not Sure \\
\hline \multicolumn{6}{|l|}{ Party } \\
\hline Democrat $(37 \%)$ & $7 \%$ & $32 \%$ & $24 \%$ & $24 \%$ & I $3 \%$ \\
\hline Republican (24\%) & $2 \mathrm{I}$ & 37 & 24 & 6 & I 2 \\
\hline Independent $(27 \%)$ & I I & 36 & 28 & I3 & $\mathrm{I} 2$ \\
\hline \multicolumn{6}{|l|}{ Ideology } \\
\hline Very Liberal (9\%) & 8 & 30 & 24 & 32 & 6 \\
\hline Liberal (I8\%) & 5 & 32 & 29 & 22 & I 2 \\
\hline Moderate (34\%) & IO & 34 & 27 & I 8 & I I \\
\hline Conservative (2 I \%) & 20 & 37 & 23 & 7 & I3 \\
\hline Very Conservative (I I \%) & 26 & 40 & I I & 8 & I6 \\
\hline \multicolumn{6}{|l|}{ Race } \\
\hline White $(72 \%)$ & I3 & 35 & 25 & I5 & I 2 \\
\hline Black ( I I \%) & I3 & 36 & I 8 & I6 & I6 \\
\hline Hispanic (I3\%) & I4 & 32 & $2 \mathrm{I}$ & I8 & I5 \\
\hline \multicolumn{6}{|l|}{ Education } \\
\hline No High School (7\%) & 20 & 37 & I6 & I I & I6 \\
\hline High School (40\%) & I3 & 38 & I9 & I3 & I6 \\
\hline Some College (22\%) & I3 & 35 & 29 & I5 & 7 \\
\hline 2-year Degree $(7 \%)$ & I6 & 27 & $3 \mathrm{I}$ & $\mathrm{I} 7$ & 9 \\
\hline 4-year Degree (I6\%) & 9 & 33 & 27 & $\mathrm{I} 7$ & I4 \\
\hline Post-graduate (9\%) & I I & 30 & 27 & 22 & I I \\
\hline \multicolumn{6}{|l|}{ Generation } \\
\hline Born Before I928 (г\%) & 8 & $3 \mathrm{I}$ & 30 & 0 & 30 \\
\hline I928-I945 (I4\%) & I4 & 40 & I 8 & I3 & I5 \\
\hline I946-I960 (33\%) & I4 & 32 & 22 & I 8 & I4 \\
\hline I96I-I973 (23\%) & I3 & 39 & 2 I & I 2 & I5 \\
\hline I974-I990 (29\%) & I I & 33 & $3 \mathrm{I}$ & I6 & 8 \\
\hline \multicolumn{6}{|l|}{ Income } \\
\hline Ist Quintile & I I & $4 \mathrm{I}$ & 22 & I5 & I 2 \\
\hline 2nd Quintile & I 2 & $3 \mathrm{I}$ & 27 & I6 & I3 \\
\hline 3rd Quintile & I4 & 28 & 27 & $\mathrm{I} 7$ & I4 \\
\hline 4th Quintile & I6 & 39 & 25 & IO & 9 \\
\hline 5th Quintile & I4 & 36 & 23 & I7 & 9 \\
\hline
\end{tabular}




\begin{tabular}{|c|c|c|c|c|c|}
\hline \multicolumn{6}{|c|}{ Voter Impersonation } \\
\hline & $\begin{array}{l}\text { Very } \\
\text { Often }\end{array}$ & $\begin{array}{l}\text { Somewhat } \\
\text { Often }\end{array}$ & Rarely & $\begin{array}{l}\text { Very } \\
\text { Rarely }\end{array}$ & Not Sure \\
\hline \multicolumn{6}{|l|}{ Party } \\
\hline Democrat $(37 \%)$ & $6 \%$ & $25 \%$ & $30 \%$ & $2 \mathrm{I} \%$ & $17 \%$ \\
\hline Republican (24\%) & I I & 42 & 23 & 5 & I8 \\
\hline Independent $(27 \%)$ & 9 & $3 \mathrm{I}$ & 28 & $\mathrm{I} 7$ & I5 \\
\hline \multicolumn{6}{|l|}{ Ideology } \\
\hline Very Liberal (9\%) & 9 & 2 I & 27 & 35 & 9 \\
\hline Liberal (I8\%) & 4 & 27 & 28 & 25 & $\mathrm{I} 7$ \\
\hline Moderate $(34 \%)$ & 5 & 30 & 34 & I3 & $\mathrm{I} 7$ \\
\hline Conservative (2 I \%) & I 3 & 44 & 23 & 7 & I3 \\
\hline Very Conservative (I \% \%) & $\mathrm{I} 7$ & 36 & I9 & 4 & 24 \\
\hline \multicolumn{6}{|l|}{ Race } \\
\hline White $(72 \%)$ & 7 & 34 & 27 & I5 & I 7 \\
\hline Black ( I I \%) & I 5 & 28 & $3 \mathrm{I}$ & I I & I4 \\
\hline Hispanic (I3\%) & I4 & 26 & 26 & $\mathrm{I} 2$ & $2 \mathrm{I}$ \\
\hline \multicolumn{6}{|l|}{ Education } \\
\hline No High School (7\%) & I5 & 25 & 22 & 8 & 30 \\
\hline High School (40\%) & 8 & 37 & 22 & I I & 22 \\
\hline Some College (22\%) & I 2 & 32 & 30 & $\mathrm{I} 7$ & 9 \\
\hline 2-year Degree (7\%) & 7 & 38 & 30 & I4 & II \\
\hline 4-year Degree (I6\%) & 7 & 25 & 34 & I 8 & I6 \\
\hline Post-graduate $(9 \%)$ & 9 & 27 & $3 \mathrm{I}$ & 20 & $\mathrm{I} 3$ \\
\hline \multicolumn{6}{|l|}{ Generation } \\
\hline Born Before I928 (г\%) & 8 & 39 & 23 & 0 & 30 \\
\hline I928-I945 (I4\%) & 9 & 38 & $2 \mathrm{I}$ & I4 & I 8 \\
\hline I946-I960 (33\%) & I 2 & 30 & 26 & I 5 & $\mathrm{I} 7$ \\
\hline I96I-I973 (23\%) & 9 & 33 & 27 & I3 & I 8 \\
\hline I974-I $990(29 \%)$ & 5 & 33 & $3 \mathrm{I}$ & I5 & I6 \\
\hline \multicolumn{6}{|l|}{ Income } \\
\hline Ist Quintile & IO & $3 \mathrm{I}$ & 24 & I4 & $2 \mathrm{I}$ \\
\hline 2nd Quintile & 8 & 30 & 27 & I 4 & 2 I \\
\hline 3rd Quintile & 8 & 30 & 30 & $\mathrm{I} 7$ & I 5 \\
\hline 4th Quintile & I I & 36 & 34 & 8 & I I \\
\hline 5th Quintile & IO & 35 & 28 & I6 & I I \\
\hline
\end{tabular}




\section{APPENDIX B}

Analyses of the effects of beliefs about fraud, theft, and impersonation on the vote examined several different measures of the vote: Reported Vote in the 2006 General Election, Intention To Vote in the 2008 Primary or General Election, and Validated Vote from the 2006 Election. Specifically, the 2007 survey asked:

$\mathrm{CC}_{14}$ Did you vote in the general election in November 2006?

No

Not Sure

Yes

$\mathrm{CC}_{\text {I5 }}$ Do you plan to vote in the 2008 Presidential Primary in your state?

Yes, I will definitely vote

I will probably vote

I may vote, but I'm not sure

I will probably not vote

I do not intend to vote

The 2008 survey asked about voting in the 2006 general election and intent to vote in the 2008 general election:

Did you vote in the 2006 General Election on November 7, 2006?

No

Not Sure

Yes

Do you plan to vote in the 2008 General Election in November?

Yes, I will definitely vote

I will probably vote

I may vote, but I'm not sure

I will probably not vote

I do not intend to vote

We code as voting or intending to vote those who were sure they voted in the 2006 general election and those who stated that they would "definitely vote" in the coming election (2008 primary or 2008 general).

Table $\mathrm{B}_{\mathrm{I}}$ displays responses to these questions and the relationship between them. The data show a familiar problem of overreporting electoral participation. Seven in ten respondents in 2007 said that they voted in the 2006 general election and two in three respondents in 2008 said they did so. The actual voting rate among adults was slightly over two in five. Even with such massive overreporting, these questions have been widely studied by political scientists in order to infer who votes and why. ${ }^{52}$

\footnotetext{
52 See generally Rosenstone \& HANSEN, supra note 3I.
} 
TABLE Bi. COMPARISON OF REPORTED VOTE IN 2006 AND INTENT TO VOTE IN 2008; 2007 AND 2008 SURVEYS

\begin{tabular}{|c|c|c|c|c|c|c|c|}
\hline & \multicolumn{3}{|c|}{$\begin{array}{l}2007 \text { SURVEY } \\
\text { Intend To Vote in } 2008 \\
\text { Primary Election }\end{array}$} & \multicolumn{3}{|c|}{$\begin{array}{l}2008 \text { SURVEY } \\
\text { Intend To Vote in } 2008 \\
\text { General Election }\end{array}$} \\
\hline & & Yes & No & Number & Yes & No & Number \\
\hline \multirow{3}{*}{$\begin{array}{l}\text { Reported } \\
\text { Vote in } \\
\text { 20o6 } \\
\text { General }\end{array}$} & Yes & $85 \%$ & $\mathrm{I}_{5} \%$ & I 384 & $95 \%$ & $5 \%$ & 673 \\
\hline & No & $41 \%$ & $59 \%$ & 604 & $43 \%$ & $57 \%$ & 327 \\
\hline & All & $72 \%$ & $28 \%$ & I 988 & $78 \%$ & $22 \%$ & 1000 \\
\hline
\end{tabular}

In the 2007 survey, we were able to go beyond the standard measures of reported or intended vote, and measure the Validated Vote. Validated Vote consists of people who reported that they voted and whose names could be reliably matched to a record on the voter rolls. The survey firm that collected the data, YouGovPolimetrix, matched names, addresses, and birthdates of those in the sample to the voter files in each state and county. In most states this permits matching of individuals to the voter lists and their vote histories with a very high degree of accuracy.

Fifty-six percent of all respondents in the sample could be matched to the voter registration lists. Matching to the vote histories of the individuals revealed that $37 \%$ of the entire sample could be determined to have definitely voted in the 2006 election, compared with estimates of the voting rate in the low $40 \%$ range. This measure, although it understates the vote, is surely much closer to actual participation figures (by a factor of four) than reported or intended vote.

An improved measure of the Validated Vote can be achieved by excluding states where the quality of the matching was not as high as in other states. States were grouped into three categories according to the quality of the voter lists and the confidence in the matching techniques. The category of the highest quality states, covering $78 \%$ of all cases in the sample (I520 out of I95 I responses), consists of those states where the reliability of the matching algorithm exceeds $95 \%$. A second category consists of states where a handful of missing counties lowered the overall rating of the reliability of the algorithm. These are Alabama, Connecticut, Indiana, Maine, Maryland, Mississippi, New Jersey, New Mexico, Oregon, and Rhode Island. The lowest quality matching arose in states where the lists were unavailable or of sufficiently low quality that a highly reliable matching could not be achieved. These states are Arizona, Arkansas, Kansas, Massachusetts, Montana, New Hampshire, Utah, Vermont, West Virginia, and Wyoming. 
TABle B2. COMPARISON OF Reported AND VAlidATEd Vote, 2007 SURVEY

\begin{tabular}{|c|c|c|c|c|c|c|c|}
\hline & \multicolumn{3}{|c|}{$\begin{array}{l}\text { Entire Sample } \\
\text { Validated Vote }\end{array}$} & \multicolumn{3}{|c|}{$\begin{array}{c}\text { High Quality Subsample } \\
\text { Validated Vote }\end{array}$} \\
\hline & & No & Yes & Number* & No & Yes & Number* \\
\hline \multirow{4}{*}{$\begin{array}{l}\text { Reported } \\
\text { Vote in } \\
2006 \\
\text { General }\end{array}$} & $\begin{array}{l}\text { Did Not } \\
\text { Vote }\end{array}$ & 91\% & $9 \%$ & $54 \mathrm{I}$ & $90 \%$ & I0\% & 424 \\
\hline & Not Sure & $84 \%$ & I6\% & 64 & $8 \mathrm{I} \%$ & I9\% & 42 \\
\hline & Did Vote & $52 \%$ & $48 \%$ & I 386 & $44 \%$ & $56 \%$ & IO45 \\
\hline & All & $63 \%$ & $37 \%$ & I990 & $58 \%$ & $42 \%$ & I5 I 2 \\
\hline
\end{tabular}

* Numbers are weighted sample frequencies and may not add to the exact totals reported owing to rounding.

A third measure of validation would consist of all people who could be matched to the voter lists and all people who said that they were not registered. This measure consists of the set of all people for whom we have very high confidence in their registration status. If a valid match was found, then the respondent is registered. If a person said he or she was not registered, the matching algorithm found a valid registration in only I $\%$ of cases. This approach excluded people who said they were registered but for whom no valid registration could be found, either because the list quality in the county was poor or because they misreported their registration status. Using this screen leaves a sample of 1346 cases. Within this subsample, 770 respondents, $57 \%$, in fact voted (validated). Unfortunately, because there is such a high tendency to overreport registration ( $90 \%$ say they are registered), this approach turns out to be biased toward registered voters. 


\section{APPENDIX C \\ Data on Photo Identification}

The 2006 Cooperative Congressional Election Study interviewed 36,500 people immediately before and immediately after the 2006 general election. Among other items, the survey asked respondents who did vote whether they were asked to show photo identification when they voted. Of those who reported that they voted at a polling place in 2006 , the survey asked: "Were you asked to show picture identification, such as a driver's license, at the polling place this November?" This is the largest sample survey for which this question has been asked to date.

This survey has sufficiently large samples in each state to permit state-level estimates of frequency of requests for photo ID at the polls. Approximately half of all respondents who said that they voted (and a third of all respondents reinterviewed in 2007) said that they had been asked to show picture identification at the polls. That pattern varied greatly across states. We use the percent of the 2006 CCES sample in each state that was asked to show photo ID to measure the frequency with which photo identification is used at the polls. The percentages are shown in Table C.

Table $\mathrm{C}$ also reports the form of identification requirement in place at the time of the 2006 election according to Professors Alvarez, Bailey, and Katz. ${ }^{53}$ The varieties of laws break into two categories: states where identification is required (Photo ID Required=PR, Photo ID Requested $=\mathrm{PQ}$, and ID Required $=\mathrm{IR}$ ) and states where it is not (ID Optional=IO, Signature $=$ S, Signature Match $=S M$, State Name=N). In the first group, the average percent asked to show identification at the polls equals $78.6 \%$; in the second group, the average percent asked to show identification equals $19.2 \%$. The correlation between percent asked to show ID and the presence of an ID requirement is .88.

\footnotetext{
${ }^{53}$ See Alvarez et al., supra note 3.
} 
TABLE C. ID LAWS AND FREQUENCY OF ID REQUESTS AT POLLS IN STATES, 2006 CCES

\begin{tabular}{||l|l|l|l|l|l||}
\hline State & $\begin{array}{l}\% \text { Asked To } \\
\text { Show ID* }\end{array}$ & ID Law $* *$ & State & $\begin{array}{l}\% \text { Asked To } \\
\text { Show ID* }\end{array}$ & ID Law** \\
\hline Ind. & $99.2 \%$ & PR & Or. & $33.3 \%$ & SM \\
\hline S.D. & $98.9 \%$ & PQ & Ill. & $32.2 \%$ & SM \\
\hline N.D. & $98.4 \%$ & IR & Nev. & $31.7 \%$ & SM \\
\hline Fla. & $97.5 \%$ & PR & Minn. & $30.7 \%$ & S \\
\hline Ohio & $96.7 \%$ & IR & Wis. & $25.4 \%$ & IO \\
\hline Conn. & $96.4 \%$ & IR & Idaho & $25.2 \%$ & S \\
\hline La. & $95.7 \%$ & PQ & W. Va. & $24.7 \%$ & SM \\
\hline Colo. & $94.1 \%$ & IR & N.C. & $22.2 \%$ & N \\
\hline Haw. & $93.2 \%$ & PQ & Md. & $20.8 \%$ & IR \\
\hline Ariz. & $92.7 \%$ & IR & Pa. & $20.2 \%$ & SM \\
\hline Ala. & $90.4 \%$ & IR & Cal. & I $\% .5 \%$ & S \\
\hline Del. & $88.7 \%$ & IR & Iowa & I8.4\% & S \\
\hline Mont. & $86.6 \%$ & IR & Miss. & I $7.6 \%$ & S \\
\hline Ga. & $84.0 \%$ & IR & Mich. & I $7.4 \%$ & S \\
\hline Ark. & $83.1 \%$ & IR & Kan. & I5.9\% & S \\
\hline Va. & $78.8 \%$ & IR & N.Y. & I5.4\% & SM \\
\hline Ky. & $72.2 \%$ & IR & Wyo. & I5.0\% & N \\
\hline Alaska & $68.6 \%$ & IR & Okla. & I $4.9 \%$ & S \\
\hline Wash. & $64.4 \%$ & IR & R.I. & I $2.4 \%$ & N \\
\hline Tenn. & $63.3 \%$ & IR & N.J. & I $2.0 \%$ & SM \\
\hline S.C. & $58.3 \%$ & IR & Mass. & $9.7 \%$ & IO \\
\hline Tex. & $50.3 \%$ & IR & N.H. & $9.7 \%$ & N \\
\hline Mo. & $49.7 \%$ & IR & Vt. & $9.6 \%$ & N \\
\hline N.M. & $42.1 \%$ & IR & Me. & $6.6 \%$ & N \\
\hline Utah & $35.0 \%$ & N & Neb. & $6.1 \%$ & S \\
\hline
\end{tabular}

* Percent of reported voters in 2006 CCES who stated that they were asked to show photo ID when they voted. Source: Cooperative Congressional Election Study - Common Content (2006), supra note I9.

** Key: PR=Photo Required, PQ=Photo Requested, IR=ID Required, IQ=ID Requested, IO=ID Optional, SM=Signature Match, S=Signature, N=State Name. See Alvarez et al., supra note 3 . 


\section{APPENDIX D}

\section{TABle D. PRobit ANALYSis OF THE RELATIONSHIP BETWEEN VOTE AND BELIEFS ABOUT FRAUD, THEFT, AND IMPERSONATION}

\begin{tabular}{|c|c|c|c|c|c|c|}
\hline \multicolumn{7}{|c|}{2007 SURVEY } \\
\hline \multirow[b]{3}{*}{$\begin{array}{l}\text { Independent } \\
\text { Variables }\end{array}$} & \multicolumn{6}{|c|}{ Dependent Variable } \\
\hline & \multicolumn{2}{|c|}{ Reported Vote, 2006} & \multicolumn{2}{|c|}{ Validated Vote, 2006} & \multicolumn{2}{|c|}{$\begin{array}{l}\text { Intent To Vote in } \\
2008 \text { P.E. }\end{array}$} \\
\hline & Coeff. (S.E.) & $\begin{array}{l}\mathrm{dF} / \\
\mathrm{dx} * *\end{array}$ & Coeff. (S.E.) & $\begin{array}{l}\mathrm{dF} / \\
\mathrm{dx} * *\end{array}$ & Coeff. (S.E.) & $\begin{array}{l}\mathrm{dF} / \\
\mathrm{dx} * *\end{array}$ \\
\hline Fraud Belief & $-.02(.06)$ & -.00 & $-.0 \mathrm{I}(.05)$ & -.00 & $.06(.05)$ & .02 \\
\hline Fraud, No Opinion & $-.43(.27)$ &.$- \mathrm{I} 4$ & $-.2 \mathrm{I}(.25)$ & -.08 & $-.12(.24)$ & -.03 \\
\hline Theft Belief & $.13(.06)^{*}$ & .04 & $.03(.05)$ &. $\mathrm{OI}$ & $.05(.05)$ &. $\mathrm{OI}$ \\
\hline Theft, No Opinion & $.52(.27)$ & .12 & $.02(.26)$ &. $\mathrm{OI}$ & $.08(.25)$ & .02 \\
\hline Democrat & -.03 (.IO) & $-.0 \mathrm{I}$ &.$- \mathrm{I} 5$ (.IO) & -.06 & $.38(.09)^{*}$ & .10 \\
\hline Republican &. $\operatorname{Ig}(. \mathrm{II})^{*}$ & .05 & $.06(. \mathrm{II})$ & .02 & $.28(.09)^{*}$ & .08 \\
\hline Ideology & $.04(. \mathrm{II})$ &. $\mathrm{OI}$ & $.06(.05)$ & .02 &.- II $(.05)^{*}$ & -.03 \\
\hline Income & $.05(.0 \mathrm{I})^{*}$ & $.0 I$ & $.03(.0 \mathrm{I})^{*}$ & .01 & $.03(.01)$ & $.0 \mathrm{I}$ \\
\hline Education & $.05(.03)$ &. $\mathrm{OI}$ & $.02(.03)$ & $.0 \mathrm{I}$ & $-.03(.03)$ & $-.0 \mathrm{I}$ \\
\hline Age & $.25(.03)^{*}$ & .07 & $.20(.03)^{*}$ & .08 & $.16(.03)^{*}$ & .05 \\
\hline White & $-.08(.13)$ & -.02 &. $\mathrm{I} 3(. \mathrm{I} 2)$ & .05 & $-.30(.12)^{*}$ & -.08 \\
\hline Black &. $\mathrm{I} 6(. \mathrm{I} 8)$ & .04 & $.0 \mathrm{I}(. \mathrm{I} 6)$ & .00 & $.06(.17)$ & .02 \\
\hline South & $-.32(.09)^{*}$ & -.09 & $-.70(.09)^{*}$ & -.27 &.$- .13(.09)$ & -.04 \\
\hline Report Registered & $2.17(.17)^{*}$ & .72 & I.49 $(.23)^{*}$ & .42 & I.58 (.I 3$)^{*}$ & .57 \\
\hline Reinterview & $.78(.09)^{*}$ & .22 & $.28(.08)^{*}$ & .I I & $.19(.08)^{*}$ & .05 \\
\hline Constant & $-3.59(.38)$ & & $-2.94(.38)$ & & $-\mathrm{I} .55(.33)$ & \\
\hline $\mathrm{N}$ & \multicolumn{2}{|l|}{1467} & \multicolumn{2}{|l|}{ I I 2 I } & \multicolumn{2}{|l|}{$\mathrm{I} 470$} \\
\hline Log-Likelihood & \multicolumn{2}{|c|}{-578.75} & \multicolumn{2}{|c|}{-658.26} & \multicolumn{2}{|c|}{-668.70} \\
\hline Pseudo R-Square & \multicolumn{2}{|c|}{.30} & \multicolumn{2}{|c|}{. $\mathrm{I}_{5}$} & \multicolumn{2}{|c|}{.17} \\
\hline
\end{tabular}

* Statistically significant at .05 level. Marginal effects of statistically significant variables are shown in bold.

** $\mathrm{dF} / \mathrm{dx}$ measures the change in the probability that a person votes (reported, actual, or intended) for a unit change in a given independent variable, holding all other variables at their mean. For dummy variables, the unit change is the difference between the probability of voting given the dummy variable equals I and the probability of voting given the dummy variable equals 0 . For other variables, the unit change is one standard deviation. 


\begin{tabular}{|c|c|c|c|c|}
\hline \multirow{4}{*}{$\begin{array}{l}\text { Independent } \\
\text { Variables }\end{array}$} & \multicolumn{4}{|c|}{2008 SURVEY } \\
\hline & \multicolumn{4}{|c|}{ Dependent Variable } \\
\hline & \multicolumn{2}{|c|}{ Reported Vote, 2006} & \multicolumn{2}{|c|}{ Intent To Vote in 2008 G.E. } \\
\hline & Coeff. (S.E.) & $\mathrm{dF} / \mathrm{dx} * *$ & Coeff. (S.E.) & $\mathrm{dF} / \mathrm{dx} * *$ \\
\hline Fraud Belief & .I3 (.09) & .04 & $.20(.10)^{*}$ & .04 \\
\hline Fraud, No Opinion & $-.49(.35)$ & -.16 & $.02(.35)$ & .00 \\
\hline $\begin{array}{l}\text { Impersonation } \\
\text { Belief }\end{array}$ & -.I4 (.IO) & -.04 &.$- \mathrm{I} 5(. \mathrm{II})$ & -.03 \\
\hline $\begin{array}{c}\text { Impersonation, } \\
\text { No Opinion }\end{array}$ & $.24(.35)$ & .07 & $-.17(.36)$ & -.04 \\
\hline Democrat & $.04(.15)$ &. $\mathrm{OI}$ & $.15(.16)$ & .03 \\
\hline Republican & $.2 \mathrm{I}(. \mathrm{I} 6)$ & .06 & -.I2 (.09) & -.03 \\
\hline Ideology & $.09(.06)$ & .02 & $.05(.07)$ &. $\mathrm{OI}$ \\
\hline Income & $.03(.02)$ & $.0 \mathrm{I}$ & $.05(.02)^{*}$ & $.0 \mathrm{I}$ \\
\hline Education & $.13(.04)^{*}$ & .04 & $.05(.05)$ &. $\mathrm{OI}$ \\
\hline Age & $.25(.03)^{*}$ & .08 & $.07(.04)$ &. $\mathrm{OI}$ \\
\hline White &. $\mathrm{II}(. \mathrm{I} 5)$ & .03 & $-.02(.17)$ & -.00 \\
\hline Black & $-.32(.20)$ & -.10 & $-.30(.22)$ & -.07 \\
\hline South & $-.15(.12)$ & -.04 & -.I8 (.I3) & -.04 \\
\hline Report Registered & 2.I I (.I 8$)^{*}$ & $.7 \mathrm{I}$ & I.83 $(. \mathrm{r} 6)^{*}$ & .59 \\
\hline Constant & $-3.4 \mathrm{I}(.45)$ & & -I.5 I (.45) & \\
\hline $\mathrm{N}$ & \multicolumn{2}{|c|}{809} & \multicolumn{2}{|c|}{809} \\
\hline Log-Likelihood & \multicolumn{2}{|c|}{-322.28} & \multicolumn{2}{|c|}{$-265.9 \mathrm{I}$} \\
\hline Pseudo R-Square & \multicolumn{2}{|c|}{.30} & \multicolumn{2}{|c|}{.27} \\
\hline
\end{tabular}

* Statistically significant at .05 level. Marginal effects of statistically significant variables are shown in bold.

** $\mathrm{dF} / \mathrm{dx}$ measures the change in the probability that a person votes (reported, actual, or intended) for a unit change in a given independent variable, holding all other variables at their mean. For dummy variables, the unit change is the difference between the probability of voting given the dummy variable equals I and the probability of voting given the dummy variable equals $\circ$. For other variables, the unit change is one standard deviation. 


\section{APPENDIX E}

TABle E. ORDERED PROBIT ANALYSES OF THE FACTORS EXPLAINING BELIEFS ABOUT VOTER FRAUD, VOTE THEFT, AND VOTER IMPERSONATION

\begin{tabular}{|c|c|c|c|c|}
\hline \multirow[b]{2}{*}{$\begin{array}{l}\text { Independent } \\
\text { Variables }\end{array}$} & \multicolumn{2}{|c|}{$\begin{array}{c}2007 \text { SURVEY } \\
\text { (Subsample in } 2006 \text { and 2007) }\end{array}$} & \multicolumn{2}{|c|}{2008 SURVEY } \\
\hline & $\begin{array}{l}\text { Voter Fraud } \\
\text { Coeff. (S.E.) }\end{array}$ & $\begin{array}{l}\text { Vote Theft } \\
\text { Coeff. (S.E.) }\end{array}$ & $\begin{array}{l}\text { Voter Fraud } \\
\text { Coeff. (S.E.) }\end{array}$ & $\begin{array}{l}\text { Voter } \\
\text { Impersonation } \\
\text { Coeff. (S.E.) }\end{array}$ \\
\hline$\%$ State ID &. $\mathrm{I} 2(. \mathrm{I} 5)$ & $-.07 \quad(.15)$ & $-.08(.14)$ & $-.20(.14)$ \\
\hline Showed ID in 2006 & -.08 (.IO) & .08 (.10) & N.A. & N.A. \\
\hline Democrat & $-.29(.10)^{*}$ & -.I6 (.IO) & $-.33(. \mathrm{II})^{*}$ & $-.2 \mathrm{I}(.08)^{*}$ \\
\hline Republican & $.28(. \mathrm{II})^{*}$ & $-.23(. \mathrm{II})^{*}$ & $.2 \mathrm{I}(. \mathrm{II})^{*}$ & .I $2(.09)^{*}$ \\
\hline Ideology & $-.13(.05)^{*}$ & $.0 \mathrm{I} \quad(.05)$ & $-.16(.05)^{*}$ &.$- .16(.04)^{*}$ \\
\hline Income & $-.0 \mathrm{I}(.0 \mathrm{I})$ & $-.0 \mathrm{I} \quad(.0 \mathrm{I})$ & $.00(.0 \mathrm{I})$ & $.0 \mathrm{I}(. \mathrm{OI})$ \\
\hline Education & $-.10(.03)^{*}$ & -.I I $(.03)^{*}$ & $-.09(.03)^{*}$ & $-.07(.02)^{*}$ \\
\hline Age & $-.02(.03)$ & $-.02(.03)^{*}$ & $.04(.03)$ & $-.06(.02)^{*}$ \\
\hline White & $.14(.13)$ &.$- .15 \quad(.13)$ & $-.07(. \mathrm{II})$ & -.I9 (.09)* \\
\hline Black & $-.04(.18)$ & $-.02 \quad(.18)$ & .17 (.I5) & $.04(.12)$ \\
\hline South & .04 (.IO) & .04 (.Io) & -.07 (.IO) & $.03(.07)$ \\
\hline Cut Point I & $-2.17(.30)$ & $-2.16 \quad(.30)$ & $-1.69(.26)$ & -I.84(.27) \\
\hline Cut Point 2 & $-\mathrm{I} .25(.29)$ & $-1.27 \quad(.30)$ & $-0.79(.26)$ & $-0.77(.27)$ \\
\hline Cut Point 3 & $-0.15(.29)$ & $-0.2 \mathrm{I} \quad(.29)$ & $0.40(.26)$ & $0.48(.27)$ \\
\hline $\mathrm{N}$ & 703 & 687 & 726 & 709 \\
\hline Log-Likelihood & $-876.7 \mathrm{I}$ & -872.57 & -913.79 & -862.15 \\
\hline Pseudo R-Square & .04 &. $\mathrm{OI}$ & .05 & .05 \\
\hline
\end{tabular}

N.A. $=$ Not Asked

* Statistically significant at .05 level. 


\section{APPENDIX F}

TABLE F. SUMMARY STATISTICS

\begin{tabular}{|c|c|c|c|c|c|c|}
\hline \multirow[b]{2}{*}{ Variable } & \multicolumn{3}{|c|}{2007 SURVEY** } & \multicolumn{3}{|c|}{ 2008 SURVEY** } \\
\hline & $\begin{array}{l}\mathrm{N} \text { of } \\
\text { Cases }\end{array}$ & Mean & S.D. & $\begin{array}{l}\mathrm{N} \text { of } \\
\text { Cases }\end{array}$ & Mean & S.D. \\
\hline Report Vote $(0, \mathrm{I})$ & I990 & .700 & .460 & IO०० & .673 & .469 \\
\hline Intend Vote $(\mathrm{O}, \mathrm{I})$ & I998 & .729 & .449 & 1000 & .783 & $.4 \mathrm{I} 2$ \\
\hline Validated Vote $(\mathrm{O}, \mathrm{I})$ & 1520 & .420 & .494 & & & \\
\hline Democrat $(0, \mathrm{I})$ & 2000 & .302 & .459 & 1000 & .373 & .484 \\
\hline Republican $(\mathrm{O}, \mathrm{I})$ & 2000 & .278 & .448 & 1000 & .274 & .446 \\
\hline Ideology $(\mathrm{I}, 5)$ & I866 & 2.85 & I.OI & 928 & 2.94 & I.I3 \\
\hline $\begin{array}{l}\text { Age (in decades) } \\
\text { (I.8 to 9.9) }\end{array}$ & 2000 & 4.59 & I. 52 & 1000 & 4.50 & $\mathrm{I} .58$ \\
\hline Education $(\mathrm{I}, 6)$ & 2000 & 3.18 & I. 44 & 999 & 3.13 & I. 47 \\
\hline Income $(\mathrm{I}, \mathrm{I} 4)$ & 1770 & 7.82 & 3.42 & $88 \mathrm{I}$ & 7.76 & 3.53 \\
\hline White $(\mathrm{O}, \mathrm{I})$ & 2000 & .723 & .448 & 1000 & .718 & .450 \\
\hline Black $(\mathrm{O}, \mathrm{I})$ & 2000 &. $\mathrm{II} 2$ & .316 & 1000 & .III & .314 \\
\hline South $(\mathrm{O}, \mathrm{I})$ & 2000 & .305 & .460 & 1000 & .279 & .449 \\
\hline Report Registered $(\mathrm{O}, \mathrm{I})$ & 2000 & .883 & $.32 \mathrm{I}$ & 1000 & $.83 \mathrm{I}$ & .374 \\
\hline Reinterview $(\mathrm{o}, \mathrm{I})$ & 2000 & .500 & .500 & & & \\
\hline State ID $(.06, .99)$ & I996 & .482 & .324 & 998 & .479 & .329 \\
\hline Showed ID in $2006(0, \mathrm{I})$ & 1000 & .323 & .467 & & & \\
\hline Fraud Belief* & I 778 & 2.88 & .932 & $8 \mathrm{I} 6$ & $2.5 \mathrm{I}$ & .955 \\
\hline Fraud, No Opinion & 2000 & .085 & .278 & 1000 & .122 & .327 \\
\hline Theft Belief* & I732 & 2.82 & .922 & & & \\
\hline Theft, No Opinion & 2000 & $.08 \mathrm{I}$ & .273 & & & \\
\hline Impersonation Belief* & & & & 820 & 2.42 & .916 \\
\hline $\begin{array}{l}\text { Impersonation, } \\
\text { No Opinion }\end{array}$ & & & & 1000 & .158 & .364 \\
\hline
\end{tabular}

* Among those who have an opinion.

** Restricted to cases with non-missing values for ideology and income.

Values of binary variables. - All variables noted (O,I) are indicator variables that take two values. I means the condition or statement is true; o means it does not hold. Report Vote means the respondent reported voting in 2006 . Intend Vote means the respondent stated an intent to vote in 2008 . Valid Vote means the respondent's vote history matched that in the voter file and that the individual is recorded as voting. See Appendix B. Democrat equals I if the respondent states a Democratic party identification, and $\circ$ otherwise. Republican equals $\mathrm{I}$ if the respondent states identification as a Republican, and o otherwise. The survey ascertains racial identification as White, Black, Hispanic, Asian, Mixed, or other. White equals I if the respondent considers her- or himself to be white; Black equals I if the respondent considers her- or himself to be black; and these are o otherwise. Report Registered equals I if the respondent claims to be currently registered to vote, and o otherwise. Reinterview indicates (for the 2007 study) if the respondent participated in the $2006 \mathrm{CCES}$; it equals o if the respondent was interviewed for the first time in 2007 . Those reinterviewed are more attentive to politics and report voting at a higher rate. We looked for interactions between Reinterview and other variables but found none; differences between the Reinterview and New Interview cases manifest themselves as differences in levels, but 
not as interactions in the regressions, differences in correlations, or differences in the effects of Fraud, Theft, or Impersonation.

Values of multiple category variables. - Ideology captures the respondent's selfidentification as: $\mathrm{I}=$ Very Conservative, $2=$ Conservative, $3=$ Moderate, $4=$ Liberal, $5=$ Very Liberal. Education measures the highest level of education achieved: $\mathrm{I}=$ No High School, $2=$ High School Degree, 3=Some College, 4=Completed 2-year Degree, $5=$ Completed 4-year Degree, $6=$ Post-graduate. Income measures self-reported household income: I =Less than $\$ 1 \mathrm{IO}, 000$ income, $2=\$ 10,000$ to $\$ \mathrm{I} 4,999,3=\$ 15,000$ to $\$ 1 \mathrm{I}, 999$, $4=\$ 20,000$ to $\$ 24,999,5=\$ 25,000$ to $\$ 29,999,6=\$ 30,000$ to $\$ 39,999,7=\$ 40,000$ to $\$ 49,999,8=\$ 50,000$ to $\$ 59,999,9=\$ 60,000$ to $\$ 69,999$, I0 $=\$ 70,000$ to $\$ 79,999$, I I $=\$ 80,000$ to $\$ 99,999$, I $2=\$ I 00,000$ to $\$$ I I 9,999 , I $3=\$$ I 20,000 to $\$$ I 49,000, I $4=\$$ I 50,000 or more. 